\title{
MEKKÎ ve MEDENÎ SÛRELER BAĞLAMINDA DÜNYA VURGUSU
}

\author{
(1) Ahmet ÖZDEMIRa
}

\begin{abstract}
Öz
Kur'an, ahiret inancını ve ona hazırlanmayı ön planda tutan bir kitap olmasına rağmen dünyevi yaşantıyı da ihmal etmemiştir. Bunun bir sonucu olarak ahirete hazırlık mekanı olarak gördüğü bu dünyayı imar etmeye, kendisini yaratan Allah'ı unutmadan dünyevi nimetlerden istifade etmeye izin vermiștir. Kur'an'ın dünyaya bakışında, Mekke ve Medine'de inen ayetlerde farklılıkların olması, dini algıların değişim ve gelişim sürecine, sahip olunan imkanlardaki ve dini anlama ve anlamlandırmadaki olgunlaşmaya bağlı olarak gerçekleşmiştir.
\end{abstract}

Mekke döneminde dünya hayatında istifade edilen nimetlerin yapısı, özellikleri, inkarcıların bu nimetlere bakışları ele alınmıştır. Bunun yanında, dünya hayatının güzelliklerinin, onu isteyen ve çalışanlara verileceği yine ayetlerde yer almıştır. Diğer taraftan kendilerine verilen bunca imkanlara rağmen, kulluk görevini ihmal etmemeleri de ögütlenmiştir. Medine döneminde inen surelerde ise maddi imkanların artması sonucunda Müslümanların, kulluk anlayışlarında bir gevşeme olmaması, dünyanın, ahiretin önüne geçirilmemesi konusuna vurgu yapıldığını söyleyebiliriz. Dünya malının değersiz olduğu, nimetleri verenin Allah olduğu da yine hatırlatılan hususlardandır. Her iki dönemde anlatılan konulara baktığımızda ise dünya hayatının güzelleștirilmiş olması, oyun ve eğlence mekanı olarak tanımlanması dikkat çeken hususlardandır. Ayrıca her iki dönemde inen ayetlerde dünya ahiret dengesine vurgu yapıldığını söyleyebiliriz. Aynı zamanda, her ikisine de değer verilmesi, ama bunun yanında ahiretin, dünyanın önüne geçirilmemesi tercih edilen hususlardan olmuştur.

Bu çalışmamızda, Mekke ve Medine döneminde inen ayetlerde, Kur'an'ın dünya hayatına bakışıyla ilgili vurgulanan hususlar ortaya konmaya çalışlacaktır.

Anahtar kelimeler: Tefsir, Kur'an, Mekkî-Medenî Sureler, Dünya, İnsan, İmtihan.

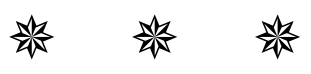

\footnotetext{
a Dr. Öğr. Üyesi, Tokat Gaziosmanpaşa Üniversitesi İlahiyat Fakültesi, ahmet.aozdemir@gop.edu.tr
} 


\section{THE PERCEPTION OF THE WORLD IN THE CONTEXT OF MECCIAN AND MEDENIAN SURAH}

The Qur'an says that the life of the world is to boast. From this point, people have superiority over others as they have. They always see themselves in a higher position. They spend time with worldly things like a child playing a game. However, they are unaware that every game is a last. Those who are aware of it better evaluate their time. Not the means prefer to aim.

God must be at the center of people's lives. The emphasis of the Qur'an is in this direction. Other elements remain in the second position. Servant must keep his author in his heart at any moment, despite the factors that keep him occupied in the world. The path he draws must be a guide to himself. Worldly objects of worship should not be an obstacle. He must spend every moment with the consciousness of worship. He, should strive to earn profit halal. He must put a distance between sins. He should know the value of his time. He must be in the consciousness that he will account for everything he does in the world in the hereafter. He should take away from his life what causes him to get away from Allah.

[The Extended Abstract is at the end of the article.]

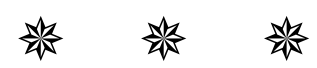

\section{Giriș}

Sûreler, genel anlamda Mekkî ve Medenî olarak iki boyutta ele alınmıştır. Bu taksimattan her birinin kendine has özellikleri vardır. Her ne kadar aynı kaynaktan gelmiş olsalar da toplumdaki değişim, muhatapların farklılaşması ve va'z edilen hükümlerin belli şartlara göre şekillenecek olması nedeniyle aralarında büyük farklar mevcuttur. En başta, içerikleri itibariyle birbirlerinden farklıdırlar. Mekke döneminde inen ayetler daha çok İslam davasını gönülden kabul etmeye bir hazırlık evresi iken, Medine'deki ayetler, bu davanın uygulama alanına girmesi amacına yönelik olarak inzal edilmiştir.

Dünya kelimesinin, "dünüv" ya da "denâet" kökünden türediği dil bilimcileri tarafından ifade edilen bir husustur. ${ }^{1}$ "Dünüv" kökünden türediği varsayıldığında mekan, zaman ve konum olarak yakın olmak, denâet kökünden türediği düşünüldüğünde ise değersiz, küçük olmak anlamında kullanıldığı görülmüştür. ${ }^{2}$ Kur'an'da yüz on civarında geçen dünya kelimesi

${ }^{1}$ Cemalüddîn İbn Manzûr, Lisânü'l-Arab, 15 cilt (Beyrut: Daru Sadr, 3.baskı, 1414), 14: 271.

2 Râgıb el-İsfehânî, el-Müfredât fî garibi'l-Kur'an, (Beyrut: Dâru'l-Marife, 4.baskı, 2005/1426), 179. 
isim olarak değil sıfat olarak kullanılmakta ve doksandan fazla yerde hayat kelimesini nitelemektedir. ${ }^{3}$

Diğer taraftan Kur'an dilinde dünya, coğrafi anlamdan ziyade ahlaki bir değer olarak tanıtılmaktadır. ${ }^{4} \mathrm{Bu}$ anlatımın göz ardı edilmesi neticesinde sanki Kur'an yeryüzünü kötülüyormuş gibi bir algı oluşturulmuştur ki bu yanlıştır. Kur'an'ın yerdiği, Allah'tan uzaklaştıran dünyevî yaşantıdır. ${ }^{5}$ Yeryüzündeki düzensizliğin, karışıklığın sebebi, insanın, Allah'a ibadet etmek yerine başkalarına yönelmesi olduğundan, ${ }^{6}$ yeryüzünün güzelleştirilmesi, ıslah edilmesi inanan insanların bir özelliği olarak Kur'an'da yer almıştır. ${ }^{7}$

Kur'an, insanların dünya hayatını düzene koymak ve ahiret hayatına insanları hazırlamak üzere gönderildiğine göre onun bu konuda söyleyeceklerinin iyi tahlil edilmesi, yaşadığımız dünyayı algılama noktasında önemli katkılar sağlayacaktır. Bu makale, Mekkî ve Medenî surelerdeki dünya vurgusuyla ilgili değişimin ortaya konmasına, her ikisinde ortak vurgu yapılan hususların ortaya çlkarılmasına yönelik olarak hazırlanmış bir çalışmadır.

\section{A. Mekkî ve Medenî Sureler Hakkında Genel Bir Bilgi}

\section{Mekkî ve Medenî Sure Taksimi}

Kur'an'da yer alan ayetlerle ilgili çeşitli tasniflerin yapıldı̆̆ görülmektedir. Ayetler, zaman, mekan ve özellikleri bakımından bir değerlendirmeye tabi tutulmak suretiyle böyle bir sonuca ulaşılmıştır. Bunlardan en belirgin olanı, Hz. Peygamber'in hayatını geçirdiği Mekke ve Medine şehirleri ekseninde yapılan değerlendirmedir. Bu çerçevede bazıları, Kur'an ayetlerini dört kısma ayırmıştır: Mekkî, Medenî, Bir kısmı Mekkî, bir kısmı Medenî, Mekkî ve Medenî olmayanlar. ${ }^{8}$ Mekkî ve Medenî sureleri belirleme kriteri olarak da üç görüş ortaya konmuştur. Birincisi: Hicretten önce inenler Mekkî, sonra inenler Medenî’dir. İkincisi: Mekke şehrinde inenler Mekkî, Medine şehrinde inenler Medenî'dir. Üçüncüsü: Mekke

\footnotetext{
3 Bkz. Yaşar Nuri Öztürk, Kuran'ın Temel Kavramları (İstanbul: Yeni Boyut, 19.baskl, 1999), 95.

4 Mustafa Öztürk, "Kur'an'ın Değer Sisteminde Dünya ve Dünyevi Hayatın Anlamı", Tasavvuf: İlmî ve Akademik Araştırma Dergisi 7: 16 (2006): 67.

5 Öztürk, Kuran'ın Temel Kavramları, 95.

6 Ebü'l-A'la Mevdûdî, Tefhîmü'l-Kur'ân, 2. Baskı. trc. Muhammed Han Kayanî ve dğr. 7 cilt (İstanbul: İnsan Yayınları, 1995), 2: 44.

7 A'râf $7 / 56$.

${ }^{8}$ Ebü'l-Fazl Celâlüddîn Abdurrahmân b. Ebî Bekr b. Muhammed el-Hudayrî es-Süyûtî eşŞâfiî. el-ítkân fî ulûmi'l-Kur'ân. Tahkîk/Tahrîc: Şuayb Arnavut (Beyrut: Müessesetü'rrisale, 1429/2008), 31.
} 
halkına hitap edenler Mekkî, Medine halkına hitap edenler Medenî'dir. ${ }^{9}$

Birinci görüş, bunlar içerisinde en meşhur olanıdır. ${ }^{10}$ Diğer görüşlere getirilen eleştiriler ve eksiklikler birinci görüşe getirilmemiştir.11 Onda vahiy, zaman bakımından tasnife tabi tutulduğu için Kur'an'ın toplumu şekillendirme sürecinin anlaşılmasına daha büyük katkı sağlamaktadır. İkinci görüşe göre Mekke ve Medine dışında inenler bu tasnife tabi olmazlar. ${ }^{12}$ Ancak Arafat, Hudeybiye gibi Mekke civarında inenler Mekkî; Bedir ve Uhud gibi Medine civarında inenler de Medenî kabul edilir. ${ }^{13}$ Uzak yerlerde inenler ise bu tasnifin kapsamı dışında kalmaktadırlar. Üçüncü görüşte de bu iki şehrin dışında yer alan insanlara yapılan hitaplar bu tasnifin dışında kalmaktadır ki bu da bir eksiklik olarak göze çarpmaktadır.

\section{Mekkî ve Medenî Surelerin Hangileri Olduğu}

Yukarıda yer alan sure tasniflerinden birincisini, yani vahyi hicretten önce ve sonra inenler şeklinde ikiye ayırdığımızda Medenî surelerin sayısının yirmi, ihtilaf edilenlerin sayısının on iki, bunların dışındakilerin de Mekkî olduğu görüşünün ortaya konduğunu görmekteyiz. ${ }^{14}$ Diğer bir görüş ise, Medenî surelerin sayısının yirmi dokuz, Mekkî surelerin sayısının seksen beş olduğ ${ }^{15}$ şeklindedir. Yaygın olan kanaate göre ise, surelerin seksen altısı Mekkî, yirmi sekizi Medenî'dir. ${ }^{16}$

Mekkî ve Medenî surelerin hangileri olduğunu tespit etmek için sahabenin görüşlerine başvurmak gerekecektir. $\mathrm{Bu}$ konuda $\mathrm{Hz}$. Peygamber'den bir rivayet gelmemiștir. ${ }^{17}$ Beyhakînnin aktardığı rivayete göre ${ }^{18}$ Mekkî ve Medenî sureleri şu şekilde tasnif etmek mümkündür:

Mekkî Sûreler: A'lâ, A'râf, Abese, Âdiyât, Ahkâf, Alak, Ankebût Asr, Beled, Burûc, Câsiye, Cin, Duhâ, Duhân, En'âm, Enbiyâ, Fâtır, Fâtiha, Fecr, Felak, Fîl, Furkân, Fussilet, Gâş̧iye, Hâkka, Hicr, Hûd, Hümeze, İbrâhîm, İhas,

${ }^{9}$ Süyûtî, el-İtkân, 31-32; Muhammed Abdülazîm Zürkânî, Menâhilu'l-irfân fî ulûmi'l-Kur'an (Beyrut: Dâru-Kuteybe, 1422/2001), 1: 243-246; Ebû Abdillâh Bedrüddîn Muhammed b. Bahâdır b. Abdillâh et-Türkî el-Mısrî el-Minhâcî ez-Zerkeșî, eș-Șâfiî. el-Burhân fî 'ulûmi'lKur’ân. Tahkîk: Muhammed Ebu'l-Fazl İbrahim (Kahire: Mektebetü Dârü't-Türâs, ts.), 1: 187.

10 Süyûtî, el-İtkân, 32; Zerkeșî, el-Burhân, 1: 187.

11 Zürkânî, Menâhilu'l-irfân, 1: 246.

12 Süyûtî, el-İtkân, 32.

13 Zürkânî, Menâhilu'l-irfân, 1: 244.

14 Zürkânî, Menâhilu'l-irfân, 1: 250.

15 Zerkeşî, el-Burhân, 1: 194.

16 Abdülhamit Birışık, "Sûre", Türkiye Diyanet Vakfı İslâm Ansiklopedisi (İstanbul: TDV Yayınlarl, 2009), 37: 538.

17 Süyûtî, el-ítkân, 32; Zürkânî, Menâhilu'l-irfân, 1: 247; Zerkeșî, el-Burhân, 1: 191.

18 Süyûtî, el-İtkân, 34. 
İnfitar, İnşikâk, İnşirah, İsrâ, Kadîr, Kâf, Kâfirûn, Kalem, Kamer, Kâria, Kasas, Kehf, Kevser, Kiyâme, Kureyş, Leyl, Lokmân, Mâûn, Meâric, Meryem, Mü'min, Mü'minûn, Müddessir, Mülk, Mürselât, Müzzemmil Nahl, Nâs, Nâziât, Nebe, Necm, Neml, Nûh, Rûm, Sâd, Saffât, Sebe, Secde, Şems, Şuarâ, Şûrâ, Tâ-Hâ, Târık, Tebbet, Tekâsür, Tekvîr, Tîn, Tûr, Vâkıa, Yâsîn, Yûnus, Yusuf, Zâriyât, Zuhruf, Zümer.

Medenî Sûreler: Ahzâb, Âl-i İmrân, Bakara, Beyyine, Cum'a, Enfâl, Feth, Hac, Hadîd, Haşr, Hucurât, İnsân, Mâide, Muhammed, Mutaffifîn, Mücâdele, Mümtehine, Münâfikûn, Nasr, Nisâ, Nûr, Ra'd, Rahmân, Saf, Tahrîm, Talâk, Tegâbün, Tevbe, Zilzâl.

$\mathrm{Bu}$ rivayette Mekkî surelerin sayısının seksen beş, Medenî surelerin sayısının ise yirmi dokuz olduğunu görmekteyiz. Bununla birlikte, Mekkî olan bir surede Medenî ayetler bulunabileceği gibi Medenî olan bir surede de Mekkî ayetler yer alabilmektedir. ${ }^{19}$ Örneğin Bakara suresi Medenî olmasına rağmen yüz dokuz ve iki yüz yetmiş ikinci ayetleri Mekkî'dir. ${ }^{20}$ Aynı şekilde, Mekke'de indiği halde hükmü Medenî olan sureler ya da ayetler olduğu gibi Medine'de indiği halde hükmü Mekkî olan ayet ya da sureler mevcuttur. ${ }^{21}$ Örneğin Ra'd suresi Mekke ehline hitap ettiği halde Medenî bir suredir. ${ }^{22} \mathrm{Bu}$ nedenle sûreler içerisinde yer alan ve o sûrenin kapsamına dahil olmayan ayetlerle ilgili farklı çalışmalar yapılmıştır. Bu noktada ilgili ayetlerin ortaya çıkarılması için belirlenen özelliklerden bir kısmını şu şekilde sıralamak mümkündür:

"Ey insanlar" hitabının olduğu, "كلا"ifadesinin yer aldığı, Bakara ve Âli İmrân sureleri hariç el-Hurufu'l-Mukattaa ile başlayan, Bakara suresi hariç Hz. Adem ve İblis kıssasının ve secde ayetlerinin yer aldığı, geçmiş ümmetlerden bahseden sureler Mekkî olarak kabul edilmiştir. ${ }^{23}$ "Ey iman edenler" hitabının bulunduğu, Ankebût hariç münafıklardan bahseden, hadlerden ve miras hukukundan bahseden sûreler de Medenî olarak kabul edilmiştir. ${ }^{24}$ Bunların dışında çok geniş bir şekilde daha farklı kriterlerin de ortaya konduğunu söyleyebiliriz.

19 Süyûtî, el-ítkân, 42; Zerkeşî, el-Burhân, 1: 199-202.

20 Süyûtî, el-İtkân, 42.

21 Zerkeşî, el-Burhân, 1: 192.

22 Zerkeșî, el-Burhân, 1: 195.

23 Süyûtî, el-İtkân, 48; Zerkeșî, el-Burhân, 1: 187-189

24 Zerkeşî, el-Burhân, 1: 187-189. 


\section{B. Mekkî Surelerde Dünya Vurgusu}

\section{Dünya Hayatının, Bitkilerin Gelișim Sürecine Benzetilmesi}

Mekke döneminde, şirk toplumunun, yaşadığı hayatı düşünmesi, orada meydana gelen ve büyük bir varlığın gücünü yansıtan gelişmelere dikkatlerinin çekilmesi amacıyla Kur'an'da dünya hayatının bitkilerin gelişim sürecine benzetildiğini görmekteyiz. ${ }^{25} \mathrm{Bu}$ anlatımda hem bitkilerin gelişim süreci ve onları halden hale dönüştüren yüce bir gücü hatırlatma hem de bugün yaşayan insanların dünyada ebedi kalmayacağı, onların da bir gün ölüp gideceği ve ona göre iyi bir yaşantı ortaya koymaları gerektiği hatırlatılmaktadır.

$\mathrm{Bu}$ örneklendirme, kendisinden çok şey beklendiği halde bekleyen kişinin hayal kırıklığına uğraması anlamına da gelmektedir. ${ }^{26}$ Bahçe sahipleri, dünyada yetiştirdikleri ürünlerden mutlaka ürün alacaklarını düşündükten sonra onların bir felaketle sonuçlanma ihtimali olduğu gibi, dünyada iken yaptıklarına güvenen, ahirete hazırlık yapmayan insanlar da ahirette felakete uğrayacaklardır. ${ }^{27}$ Burada dikkat çekilen diğer bir husus, bir süre sonra cazibesini kaybedecek olmasına rağmen insanların dünyayı sevmede ve onun güzelliklerinden istifade etmede aşırıya gitmeleridir. ${ }^{28}$ Onun için konuyla ilgili ayetlerde, sonlu olmasından dolayı dünya hayatının önemsiz, kıymetsiz olması, teșbihle anlatılmıștır. ${ }^{29} \mathrm{Bu}$ üslup, Kur'an'da zaman zaman başvurulan etkili anlatım biçimlerindendir. Gökten suyun inmesi, hayatın başlangıcına, bitkilerin birbirine karışması hayatın dinçlikgençlik çağına, insanların ve hayvanların o nimetlerden istifade etmesi, hayatın lezzetlerinden faydalanmaya, Allah'ın emrinin gelmesi, hayatın sonuna benzetilmiştir. ${ }^{30}$ Böylesi bir örneklendirme, insanların her an şahit oldukları bir durumun, günlük algılarının ötesinde, ona daha farklı bir anlam yüklemek suretiyle insanların gözlerinin önüne serilmesi ve zihinlerde yer edecek bir tarzda anlatılmasıdır.

Müfessir Elmalılı ise dünya hayatını, satılık kumaşa, kullanılan alet ve

25 Yûnus 10 /24; Kehf 18/45

26 Fahrüddîn Râzî, Mefâtîhu'l-gayb (et-Tefsîrü'l-kebîr), 32 cilt (Beyrut: Dâru İhyai'tTurasi'l-Arabiyyi, 3. Baskl, 1420), 17: 237.

27 Mevdûdî, Tefhîmü'l-Kur'ân, 2: 327.

${ }^{28}$ Ahmed Mustafa Merâğî, Tefsîru'l-Merâğî (Mısır: Mustafa Elbânî el-Halebî ve Evlâduhu, 1946), 11: 92.

${ }^{29}$ Ebu Abdillah Muhammed b. Ahmed Ebu Bekir Kurtubî, el-Câmi'u li ahkâmi'l-Kur'ân ve'l mübeyyin limâ tedammenehu mine's-Sünneti ve âyi'l-furkân (Beyrut: Müessesetü Risale, 2006), 10: 477

30 Muhammed Tahir İbn Așûr, et-Tahrir ve't-tenvir (Tunus: Daru Tunusiyye, 1984), 10: 477. 
edevata benzetmiştir. Bunların serap gibi, gökyüzündeki bulutlar gibi olduğunu, yani bir göz yanılması gibi ya da belli bir süre sonra yok olup gidecek bir nesne gibi olduğu gerçeğini hatırlatmak istemiştir. ${ }^{31}$ Dünya hayatının ve orada insanların sahip oldukları meta'nın yok olup gidecek olması, insanları düşünmeye ve kendi şahsi çıkarları için çok uzun vadeli planlar yapmamaya yönelik ikaz mahiyetindedir.

\section{Dünya Nimetlerinden İstifade Etmeye İzin Verilmiş Olması}

İnsanlar, dünyanın güzellikleri karşısında kayıtsız kalamaz ve onlardan istifade etmeye çalışır. İnsanları, dünya nimetlerini tamamen terk edip yeni bir dine ve ahirette elde edecekleri ödüle yönlendirmek kolay bir hadise olmasa gerektir. 0 nedenle Kur'an, sahip oldukları nimetlerden istifade etmek suretiyle de kişilerin İslam'a girebileceklerini, ama bu noktada bazı kriterlere uymaları gerektiğini, İslam'ın ilk muhatapları olan ve dünyevî mutluluğu hedef olarak gören Mekke müşriklerine hatırlatmaktadır. ${ }^{32}$

Görüldüğü gibi Kur'an, insanların, Allah'ın kendilerine vermiş olduğu nimetleri isteme ve ona vesileler arama hakları olduğuna işaret etmektedir. ${ }^{33}$ Allah, kazanç yolları aramayı, ticaret yapmayı, kazanç elde etmeyi teşvik etmiştir. Çalışmadan sadece tevekkül ederek nimetlerin hazır olarak gelmesini beklemek büyük bir yanılgıdır. Tevekkül, çalışmakla birlikte olur. ${ }^{34}$ Zaten Kur'an'ın, dünya için çalışmayı gereksiz gördügü gibi bir yanılgıya düşmek doğru olmayacaktır. İnşirah suresindeki "Boş kaldın mı hemen (başka) işe koyul" 35 buyruğu da sürekli bir çaba ortaya koymaya teşvik mahiyetindedir. Kur'an'ın eleştirdiği, yalnızca dünyayı isteyenlerin tavrıdır. ${ }^{36}$ Ama bu ve benzeri ayetlerde, dünyevi nimetlerden istifade ederken o nimetleri verenin Allah olduğunun unutulmaması, ${ }^{37} 0$ 'na isyan edilmemesi uyarısı da mevcuttur. ${ }^{38}$ Kulluk görevi ihmal edilmediği sürece, helal olmak kaydıyla, dünyanın güzelliklerinden faydalanmaya, Maide suresinin seksen yedinci ayetinin de işaret ettiği gibi izin verilmiştir.

\footnotetext{
31 Elmalılı M. Hamdi Yazır, Hak Dini Kur'an Dili (İstanbul: Azim Yayınları, ts.), 4: 476.

32 Mülk 67/15.

33 Nasıruddin Ebu Said Abdullah b. Ömer b. Muhammed eş-Şirazî el-Beyzâvî, Envâru'ttenzîl ve esrâru't-te'vîl (Beyrut: Daru İhyai't-Turasi'l-Arabiyyi, 1418), 5: 230.

34 Merâğî, Tefsîru'l-Merâğ 1 i, 29: 15.

35 İnşirâh 94/7.

36 Tuncer Namlı, "Kur’an ve Dünyevileşme ya da Bir Dünya Görüşü Kırılması”, Eski Yeni: Üç Aylık Düşünce Dergisi 13 (2009): 46.

37 Mevdûdî, Tefhîmü'l-Kur'ân, 6: 421.

${ }^{38}$ Râzî, Mefâtîhu'l-gayb, 30: 591.
} 


\section{Dünyanın Cazibesinin İnsanı Aldatabilecek Güçte ve Geçici Olması}

Göz kamaştıran dünya güzelliklerinin, insanı etkisi altına alabilmesi için bir cazibesinin olması gerekir. Cazibesi olmayan bir şeye insanların değer vermesi mümkün değildir. Bu cazibesinin, insanlar için tehlikeli tarafi, kişinin, onun büyüsüne kapılarak haram-helal ayrımı yapmadan ondan istifade etmeye ve kendisini günaha sevk etmeye yönelmesidir. Mekke müşriklerinin, kendi zenginliklerinin, onları değerli kıldığı ve peygamber gelecekse onlardan birine gelmesi gerektiği şeklindeki anlayışları, dünyanın bu cazibesinin etkisinde kalarak onu temel bir kriter olarak gördüklerini göstermektedir. İlgili ayetler, ${ }^{39}$ onların bu niteliklerini ortaya koyma ve uyarma amacına yöneliktir.

Hiç şüphesiz, Mekke müşrikleri ve onlarla aynı çizgide yer alan insanlar, Kur'an ve hadislerde yer alan tasvirlerle alay ettikleri için meselelere dar bir çerçeveden bakmaktadırlar. ${ }^{40}$ Allah'ın yarattı̆̆ı nimetler üzerinde düşünmek yerine onları sadece tüketmeyi amaç edindikleri için dünyanın aldattığı kişiler olmuşlardır. ${ }^{41}$ Aldatılmaları, dini hakikatlerden yüz çevirmeleri, dünyanın güzellikleriyle yetinmeleri anlamına da gelmektedir. ${ }^{42}$ Dünyanın aldattığı kişiler, sonunda ahireti dahi inkar edecek duruma gelmektedirler. ${ }^{43}$ Onların, sahip oldukları imkanlara yüzeysel bakışları, eşyanın hakikatini anlamalarına, onları tefekkür etmelerine ve bunun sonucunda da hakikate ulaşmalarına engel teşkil eden bir husus olmuştur.

Diğer taraftan, dünyanın aldatıcı olması, geçici olmasıyla bağlantılı olan bir meseledir. Kur'an'da, ${ }^{4}$ şirk toplumunun, geçici olan dünya hayatının güzelliklerini, değerliyi ve değersizi belirleme noktasında temel kriter olarak görmeleri eleştirilerek, onların bu algılarının yanlış olduğu, yok olup gidecek bir şeyin, daha kıymetli olana tercih edilmesinin bir yanılgıdan ibaret olduğu gerçeği hatırlatılmaktadır.

Biliyoruz ki, ahirete kıyaslandığı zaman dünya nimetleri geçici ve miktar olarak da çok azdır. Ayrıca dünyadaki maddi ve manevi imkanlarının

39 En'âm 6/70. Benzer ayetler için bkz. En'âm 7/130; A'râf 7/51; Fâtır 35/5; Lokman $31 / 33$.

40 Mevdûdî, Tefhîmü'l-Kur'ân, 2: 41.

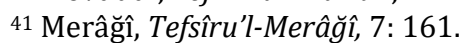

42 Râzî, Mefâtîhu'l-gayb, 13: 24.

43 Beyzâvî, Envâru't-tenzîl, 2: 167.

44 "Dünyada bir miktar geçim (sağlarlar), sonra dönüşleri bizedir; sonra da inkâr etmekte oldukları şeylerden ötürü onlara şiddetli azabı tattırırız." Yûnus 10/70. 
ahirette kendilerini kurtaracağını iddia edenler de yanılgı içerisindedirler. ${ }^{45}$ Belli bir zaman diliminde yaratılmış olan insanların ihtiyacını karşılamak üzere verilen nimetlerin, ebedi hayattakilerle klyaslanması elbette ki mümkün değildir.

\section{Dünya Hayatındaki Zenginliğin İnkarcılara Onları Daha Çok Saptırmak İçin Verilmiş Olması}

Müşriklerin önde gelenleri, imkanları kısıtlı olan zayıf Müslümanlara karşı hakaretvari davranışlar sergilemekte, maddi imkanlarının, kendilerinin daha değerli, inanan insanların ise daha değersiz olduklarının göstergesi olduğunu iddia etmekteydiler. Bu durumun, Müslümanlarda bir tereddüt meydana getirmemesi için Allah, Kur'an'da, ${ }^{46}$ maddi varlığın her zaman iyi neticeler doğurmayacağl, kişinin daha çok azgınlaşmasına sebep olabileceği gerçeğini hatırlatmaktadır.

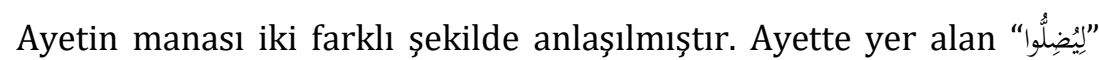
kelimesindeki " $"$ " harfine verilen harekeye göre bu kişilerin kendilerinin doğru yoldan sapması ya da başkalarını saptırmaları şeklinde iki farklı mana verilmiştir. ${ }^{47}$ Her ikisi de mümkün olmakla birlikte tefsirlerde daha çok birinci manaya göre yorumlar yapıldığını görmekteyiz.

Şurası bir gerçektir ki, inkar edenlere nimetlerin verilmiş olması, onlara değer verildiği anlamında değil istidrac kabilinden kabul edilmiştir. 48 Muhtemeldir ki kendilerine nimet verilmiş olmasını ya kendilerinden bilmekte ya da doğru yolda olmalarının buna sebep olduğu zannını taşımaktadırlar. $\mathrm{Bu}$ nedenle de verilen nimetlerin, aslında onların sapkınlıklarına son vermeleri amacına yönelik olması mümkün olmakla birlikte inkarlarına devam ettikleri, durumlarını düzeltmedikleri görülmektedir. ${ }^{49}$

Ne var ki, dünyevileşen insan, kendisine onca nimet veren Allah'ın emir ve yasaklarına uymak bir tarafa O'na kafa tutmaya, yaratıcıyı hayatının dışına atıp kendini tanrılaştırmaya yönelik adımlar atmaktadır. ${ }^{50}$ Tarihte görüyoruz ki, malı çok fazla olan kişilerin kibirlenerek haktan yüz çevirmeleri, azgınlaşmaları hatta öldükten sonra bile zinet eşyalarını diğer

\footnotetext{
45 Merâğî, Tefsîru'l-Merâğ̂̂, 11: 136.

${ }^{46}$ Yunus 10/88.

${ }^{47}$ Muhammed b. Cerîr et-Taberî, Câmi'u'l-beyân 'an te'vîli âyi'l-Kur'ân, 4 cilt (Kahire: Daru Hicr, 1422/2001), 12: 261.

48 Beyzâvî, Envâru't-tenzîl, 3: 122.

49 Râzî, Mefâtîhu'l-gayb, 17: 292.

50 Namlı, "Kur'an ve Dünyevileşme ya da Bir Dünya Görüşü Kırılması", 45.
} 
insanlara bırakmayarak mezarlarına koydurmaları, ${ }^{51}$ dünyevileşmenin zirve noktasını teşkil etmektedir.

\section{Sadece Dünyayı İsteyene Onun Verileceği}

Mekke müşriklerinin, sahip oldukları maddi imkanlarının, onların Allah katında değerli oldukları, bu nedenle de kendilerinin zengin kılındığı anlamına gelmediği, Allah'ın bu dünyada koymuş olduğu ilahi kanun gereği, dünya nimetlerini elde etmek için istemenin ve onun için çalışmanın yeterli olacağı gerçeği Kur'an'da vurgulanan ${ }^{52}$ hususlardandır.

Ayette yer alan uyarı sadece dünyayı isteyen ve yalnızca onun için çalışanlar hakkındadır. Onlar, bu konuda tercihlerini özgür bir şekilde ortaya koymuşlardır. ${ }^{53}$ Hayatı bu dünyadan ibaret görüp ahirete inancı olmayan, bu kişilerin, oradaki mükafat ve cezayı kabul etmeleri beklenmediğinden dünyadaki çabalarına göre bu dünya için emeklerinin karşılığı verilecektir. ${ }^{54}$ $\mathrm{Bu}$ inançlarının bir sonucu olarak peygamberlerin davetine icabet etmedikleri için de ahirette elde edecekleri tek şey azap olacaktır. ${ }^{55}$

Ahireti öteleyen ve hedef olarak bu dünyayı elde etmeye odaklanan bu kişilerin ahirete hazırlık anlamında bir çaba ortaya koymaları beklenemez. ${ }^{56}$ Onlar, adeta taparcasına yalnızca bu dünya için çalışırlar. Hedefleri maddi nesnelerdir. Onlarda kişisel sorumluluk ve Allah'a kulluk bilinci yoktur. ${ }^{57}$ Kişiliği dünyalık menfaat temeli üzerine kurulu bir insanın sahip olduğu malı kendisinden daha ön planda yer alacak ve başkaları, onlardan önce mallarını görecektir. ${ }^{58} \mathrm{Bu}$ da insanın ihtiyacını karşılamak için yaratılan eşyaya kulun hizmet etmesi, hayatını ona adaması anlamına gelecektir.

Dikkat edilecek olursa ayetteki vurgu, ahireti ihmal etmek suretiyle dünya için çalışmaya yöneliktir. Hayatını devam ettirmek, ailesinin ihtiyaçlarını karşılamak, toplumsal ve dini sorumluluklarını yerine getirmek için ortaya konan çaba ve bunun sonucunda elde edilen kazanç, zemmedilen bir durum değildir. Hatta bu gereklidir. Çalışan ve kazanan mümin, çalışmayıp tembellik edenden her zaman daha değerlidir.

\section{Hayatı Bu Dünyadan İbaret Görmenin Yanlışlığı}

Cahiliye döneminde Mekke'de devam eden yaşantı, ibadeti sadece

51 Merâğ̂̀, Tefsîru'l-Merâğ̂̂, 11: 148.

52 İsrâ $17 / 18$.

53 Beyzâvî, Envâru't-tenzîl, 3: 251.

54 Taberî, Câmi'u'l-beyân, 14: 536.

55 Râzî, Mefâtîhu'l-gayb, 20: 316.

56 Merâğî, Tefsîru'l-Merâğ 1 î, 15: 27.

57 Mevdûdî, Tefhîmü'l-Kur'ân, 3: 101.

58 Namlı, "Kur'an ve Dünyevileşme ya da Bir Dünya Görüşü Kırılması", 44. 
sembolik bazı görevleri yapıp onun dışında dini, hayatın dışına atma ve dünyevî makam ve zenginliği temel ölçü olarak kabul etmeden öteye geçmiyordu. Oradaki hayat, ölmüş bir insanın kemiklerini eline alıp parçalayarak "bunları tekrar kim diriltilecek" 59 diyecek kadar dünyevileşmiş ve bundan sonraki hayatı inkar eder bir duruma gelmiști. İște Kur'an'daki bazı ayetler,60 müşriklerin bu anlayışlarının yanlışlığını ortaya koyar mahiyettedir.

Ayetlerde işaret edilen bu kişiler, Allah'ın, insanları tekrar dirilteceğine inanmayan, ahireti kabul etmeyen müşriklerdir. Ahiret inançları olmadı̆̆ı için peygamberi tasdik etme ve salih amel işleme yönünde bir çabalarının olması da beklenemezdi. ${ }^{61}$ Zaten hayatı bu dünyadan ibaret görmek, tekrar dirilmeyi, hesaba çekilmeyi inkar etmek anlamına gelir ki bu tür insanlar kıyamet günü tekrar dünyaya gönderilmiş olsalar yine aynı inkarcılıklarına devam edecekler, ${ }^{62}$ düşüncelerinde herhangi bir değişme olmayacaktı. ${ }^{63}$

Aslında müşrik Araplar, insanın bu dünyada ebedi kalmayacağının ve bir gün öleceğinin farkındaydılar. Çünkü bu durum, gözleri önünde cereyan eden ve inkar edilemez bir gerçekti. Ama onlar, insanın, öldükten sonra hesaba çekileceğini inkar ediyor, yok olup gideceğini düşünüyorlardı. 64 Kısaca onların inancı, ölümü değil ahireti inkar etme temeline dayalıydı.

\section{Hayatın Merkezinde Kulluk Olması}

Ahiret, dünya hayatının ayrılmaz bir parçası olarak kabul edilince ona yönelik bir hazırlığın yapılması kaçınılmaz olacaktı. Cahiliye Mekke toplumunda olduğu gibi sembolik bazı ibadetler yapmak yerine tüm hayatı kapsayacak bir kulluk anlayışının zihinlere yerleştirilmesi, Allah'a kulluğu, vazgeçilmez bir hayat düsturu olarak görmeyi ve diğer bütün meşguliyetlerin buna göre şekillenmesini öngörüyordu. Kur'an'da yer alan ibadet anlayışı da ${ }^{65}$ böyle bir sorumluluk çerçevesi çizmekteydi.

Kuşkusuz herkes, Allah'ın kuludur ve O'na karşı kulluk görevini layıkıyla yerine getirmeye çalışmalıdır. Allah, bütün insanları önce kendisine

\footnotetext{
59 Yâsîn 36/78.

60 "Onlar, hayat ancak bu dünyadaki hayatımızdan ibarettir; biz, bir daha da diriltilecek değiliz, demişlerdi." En'âm 6/29. Benzer ayetler için bkz.; Yûnus 10/7; Mü’minûn 23/37.

61 Taberî, Câmi'u'l-beyân, 9: 213.

62 Râzî, Mefâtîhu'l-gayb, 12: 511.

63 Merâğ

64 Öztürk, "Kur'an'ın Değer Sisteminde Dünya ve Dünyevi Hayatın Anlamı", 73.

65 "De ki: Şüphesiz benim namazım, kurbanım, hayatım ve ölümüm hepsi âlemlerin Rabbi Allah içindir." En'âm 6/162. Ayrıca bkz. Hicr 15/99; Zâriyât 51/56.
} 
iman etmeye ardından da ibadet etmeye davet etmektedir.66 İnsanların yanında cinleri de aynı amaca yönelik olarak yaratmıştır. ${ }^{67}$ Bu nedenle aciz olan insan, isteyerek veya istemeyerek kulluğunu ikrar etmek durumundadır. ${ }^{68}$ Ayrıca İbadete devamlılıkta emredilmektedir. Allah'a itaat etmek ve hükümlerini uygulamak da bu kapsamdadır. Bunu inananlar gönülden yaparken inkarcılar kerhen yapmaktadırlar. Yine bunu müminler hem zor zamanlarında hem de refah içerisinde oldukları durumlarda yaparlarken inkarcılar, ancak zor zamanlarda bunu yapmaktadırlar. ${ }^{69}$ İbadet ve kulluk konusundaki uyarı tüm insanlara olmakla birlikte asıl hatırlatma inkarcılaradır. ${ }^{70}$ Allah'ın, kulların ibadetine ihtiyacı olmamakla birlikte muhtaç olan kuldur. Zaten imtihan da bunu gerektirmektedir.71 Diğer taraftan bir insanın Müslüman oluşu, her şeyden önce bencilliğinden, kendi gücüne güvenmekten vazgeçip alçak gönüllü bir kul olarak efendisi Allah'ın huzurunda durmasını gerektirmektedir. ${ }^{72}$ Yaratıcı karşısında kibre kapılmak ve kulluk etmekten imtina etmek aynı zamanda dünyaya gönderiliş amacına aykırı bir davranış olacaktır.

Bu vesileyle şunu da bilmek gerekir ki, Allah'a kulluk, sadece ahirette ödül kazandırmaz. Dünyada da karşılaşılan sorunlara karşı kişideki dayanma gücünü artırır. Huzurlu, cesaretli bir yapıya bürünerek engellerin daha kolay bir şekilde aşılmasını sağlar. ${ }^{73}$ Mekke dönemindeki Müslümanların, kendilerine yapılan onca işkenceye, eziyete rağmen davalarından vazgeçmemeleri, kulluğun kendilerine verdiği güç sayesinde olmuştur. Kulluk deyince sadece temel ibadetlerin akla gelmesi gibi bir yanılgı söz konusudur. Kulluk, dünyaya gönderiliş amacının farkında olup bütün davranışlarını ona göre şekillendirmeyi ifade eder. Cahiliye Mekke toplumunda bu inanç kaybolduğu için müşriklere bu yaratılış gayesi

66 Bkz. Beyyine 98/7; Ra'd 13/29; Tâhâ 20/82.

${ }^{67}$ Ebu Muhammed Abdulhak b. Galib b. Abdurrahman b. Temam b. Atiyye el-Endelûsî elMuharibî, el-Muharraru'l-vecîz fì tefsîri'l-Kitâbi'l-Azîz (Beyrut: Daru'l-Kütüb el-İlmiyye, 1422), 5: 182.

68 İbn Kesir, Tefsîru'l-Kur'âni'l-Azîm, 13: 222.

${ }^{69}$ Şemsüddin Muhammed b. Ahmed el-Hatib eș Şirbinî eş-Şafî, es-Siracü'l-münir fi'l-İaneti ala mağrifeti ba'di meani kelami Rabbina el-Hakim el-Habir (Kahire: Matbaatu Bulak, 1285), 4:107.

70 Muhammed b. Ali b. Muhammed b. Abdullah eş-Șevkânî, Fethu'l-Kadir (Dımeşk: Daru İbn Kesir, 1414), 4: 105.

71 Ebu Zeyd Abdurrahman b. Muhammed b. Mahluf es-Seâlibî, el-Cevahiru'l-Hisan fi Tefsiri'l-Kur'an (Beyrut: Daru İhyai't-Turasi'l-Arabiyyi, 1418), 4: 203.

[54| $\quad 72$ Toshihiko İzutsu, Kur'an'da Allah ve Insan, (Çev. Süleyman Ateş) (Ankara: Ankara Üniversitesi Basımevi, 1975), 190.

73 Mevdûdî, Tefhîmü'l-Kur'ân, 2: 585. 
öncelikle hatırlatılmıștır.

\section{Medenî Sûrelerde Dünya Vurgusu}

\section{Dünya Hayatını Tercih Eden Müminlerin Uyarılması}

Medine döneminde maddi anlamda güçlenen müminlerin manevi anlamda da güçlenmeleri, hayatlarına yeni giren bazı ibadet sorumluluklarını hakkıyla yerine getirmek üzere çaba ortaya koymaları, kulluk hayatlarını sekteye uğratacak derecede dünyevi yaşantıya meyletmemeleri Kur'an' $\mathrm{da}^{74}$ kendilerine hatırlatılmaktadır.

Burada söz konusu olan, inanan insanların, ahirette alacakları sevaptan fedakarlık ederek, ahiretle kıyaslandığında değersiz olan dünyayı tercih etmeleridir. ${ }^{75}$ Yani, ayette, müslümanların güçlenmesi adına dünyalık bir mal elde etmek değil, ahireti göz ardı ederek sırf dünya menfaatini düşünmek yerilmiştir. ${ }^{76}$ Oysa, Allah'ın, müminler için istediği şeyin talep edilmesi ve kişisel arzuların peşinde koşulmaması halinde, ahiret de ihmal edilmediği sürece müslümanlara galip gelinemeyeceği,77 Allah'ın buna gücünün yeteceği bilinmesine rağmen buna aykırı hareket edilmesi nedeniyle Hz. Peygambere ve ashabına hatırlatmada bulunulmuştur. ${ }^{78}$

Bu yüzdendir ki Cuma suresinde ${ }^{79}$ dünyalık bir mal elde etmek adına Hz. Peygamber'i bir Cuma hutbesi esnasında yüzüstü bırakıp giden müminler, Allah katında verilecek sevabı değil de dünyalık bir menfaati tercih ettikleri için uyarılmışlardır.

2. Dünya Nimetleri İçerisinde Kaybolmanın, Onlara Aşırı Meyletmenin Münafıkların Özelliği Olarak Anlatılması

Medine döneminde müşriklerin yerini münafıklar ve Ehl-i kitap aldığ için örneklemeler daha çok onlar üzerinden yapılmıştır. Münafıklardan bahseden bir ayette, ${ }^{80}$ onların, dünya malına aşırı düşkünlüğünden bahsedilmektedir. Bu ve benzeri ayetlerden anlıyoruz ki, doğru olmadığ ifade edilen Müslüman davranışı, dünya malını kazanmak ve ondan istifade etmek değil, onun içerisinde kaybolarak asıl dünyaya gönderiliş amacını unutmaktır. Çünkü dünya nimetlerine karşı gösterilen aşırı hırs, kişinin gönlünü ve zamanını onlarla meşgul etmesine, kulluk görevini ihmal

74 Enfâl 8/67.

75 Beyzâvî, Envâru't-tenzîl, 3: 67.

76 Râzî, Mefâtîhu'l-gayb, 15: 510.

77 Taberî, Câmi'u'l-beyân, 11: 271.

78 Merâğ

79 Cuma 62/11.

80 "(Ey münafiklar! Siz de) sizden öncekiler gibi (yaptınız). Onlar sizden kuvvetçe daha üstün, mal ve evlâtça daha çok idiler..." Tevbe 9/69. 
etmesine ve bu yolda yanlış davranışlar ortaya koymasına sebep olabilmektedir.

Her dönemde insanlar, daha çok, mallarıyla ve evlatlarıyla imtihana tabi tutulmuşlar, bu imtihanda münafıklar, bütün gayretlerini bunları elde etme yolunda kullanmış ve bunun sonucunda daha da azgınlaşmışlardır. ${ }^{81}$ $\mathrm{Bu}$ özellikleriyle onlar da, dünya hayatına aşırı düşkünlükleriyle bilinen ve Kur'an'ın ifadesiyle dünyada bin sene yaşamış olmayı arzu eden İsrailoğullarına benzemişlerdir. ${ }^{82}$ Onlar, gerçek lezzetleri elde etme yolunda bir çaba ortaya koymayıp geçici lezzetlerle yetinmeyi tercih etmişlerdir. ${ }^{83}$ İkiyüzlü vasıfları nedeniyle gizli hallerinin ortaya çımasından endişe eden münafıkların, dünyaya bakış açılarının inkarcılarla aynı olduğu, peygambere itaati değil, dünyevi kazancı tercih ettikleri olumsuz bir davranış tarzı olarak ortaya konmuştur. ${ }^{84}$ Gizli hallerinin ortaya çıkması endişesi yaşamaları da zaten ahiretle ilgili değil dünyevi bir kaygı nedeniyledir. Maddi imkanlarının kendilerine huzur getirmediği, sürekli bir korku ve endişe içerisinde yer aldıkları Bakara sûresinin ilk ayetlerinde tasvir edilmekte ve yaşantılarının imrenilecek bir tarafının olmadı̆̆ı hatırlatılmaktadır.

\section{Dünya Hayatının Yol Azığı Olarak Nitelendirilmesi}

Özellikle savaşlarda elde edilen ganimetlerle maddi imkanları artan Medine'deki Müslümanlara, bu imkanların yalnızca bir araç olduğu, kullanıldıktan sonra yok olacağı, geçici olanın asıl olana tercih edilmemesi gerektiği Kur'an'da hatırlatılan hususlardandır. ${ }^{85}$ Azık tabiri, kısa süreli yolculuklar için kullanıldığından, dünyanın da kısa süreli olduğuna işaret edilmektedir.

Biliyoruz ki dünya nimetleri ahiretle kıyaslandığında bir çobanın azığı mesabesindedir. Az bir süre faydalanılıp sonra yok olacaklardır. ${ }^{86}$ Ebedî olan bir hayata nispetle hem zaman açısından hem de miktar açısından son derece azdır. ${ }^{87} 0$ nedenle şımarmaya, insanlara karşı küstahlaşmaya değmeyecek bir yapıdadır. ${ }^{88}$ Ayrıca dünya malının azık olarak nitelendirilmesi, yolculuk esnasında insanların hiç ummadıkları durumlarla karşılaşmaları ihtimaline karşı o azığı iyi değerlendirmeleri, yolculuk esnasında asıl hedefi

81 Merâğî, Tefsîru'l-Merâ̆̆̂̂, 10: 157.

82 Taberî, Câmi'u'l-beyân, 11: 552.

83 Beyzâvî, Envâru't-tenzîl, 3: 88.

84 Râzî, Mefâtîhu'l-gayb, 16: 98.

$85 \mathrm{Ra}^{\prime} \mathrm{d} 13 / 26$.

86 Beyzâvî, Envâru't-tenzîl, 3: 187.

87 Taberî, Câmi'u'l-beyân, 13: 516.

88 Merâğî, Tefsîru'l-Merâğ îl, 13: 99. 
unutmamaları ve o hedefe ulaşmalarına engel teşkil edecek tavırlardan uzak durmaları anlamı da taşımaktadır.

Görüldüğü gibi Kur'an, insan için asıl hayatın ahiret olması gerektiğini söylemektedir. ${ }^{89} 0$ nedenle insanı asıl mutlu edecek olan şey dünya nimetleri değil, ahirette elde edeceği büyük kazançtır. Yalnızca dünya nimetleriyle huzur bulan kişiler, Allah'a itaat edenlere O'nun ahirette vereceği güzellikleri, nimetleri, ikramları bilmedikleri ya da inanmadıkları için mutluluğu sadece bu dünyadaki nimetlerde aramaktadırlar. ${ }^{90}$ Dünya nimetlerini elde etmek için gayri ahlaki yollara başvursalar dahi bunların kendilerini rahatsız etmiyor olması, aynı zamanda onlardaki olumsuz bir karakterin göstergesidir. ${ }^{91}$ Her ne kadar bu mesele daha çok inanç boyutuyla ele alınıyor olsa da, diğer insanların hakkını gasp etmenin, onlar üzerinden haksız kazanç elde etmenin ahlaki bir boyutunun da olduğu, insanca davranış ortaya koymanın, her tür inanca sahip toplum kesimlerinde de zaruri olduğu yadsınamaz bir gerçektir.

\section{Dünya Menfaatinin, Müminlere Karşı Kişiyi Düşmanlığa ve}

\section{Günah İşlemeye Sevk Etmemesi Gerektiği}

İnsanlar arasında büyük sorunlara sebep olan dünya malının, tarihte görülmemiş bir kardeşlik örneği sergileyen Ensar ve Muhacir arasındaki bu birlikteliği ortadan kaldırmaya sebep olmaması, müslümanların, zor zamanlarda olduğu gibi refah seviyesinin yüksek olduğu dönemlerde de bu kardeşliği korumaları, dünyalık menfaatin bu kardeşliğin önüne geçmemesi gerektiği Kur'an'da üzerinde durulan hususlardandır. ${ }^{92}$

Konuyu yukarıda yer alan ayet bağlamında düşündüğümüzde, dünyada iken geçici ganimeti elde etmek için iyice araştırmadan bir mümini öldürmek yerine Allah'ın ahirette vereceği mükafatı düşünmenin ve ona göre hareket etmenin tercih edilmesi gerektiği ifade edilmiştir.93 Kişinin Müslüman olup olmadığını araştırmak, şüphe üzerine dünyalık bir menfaat için Müslüman bir şahsiyete zarar vermek İslam'a uygun bir davranış tarzı olarak görülmemiştir. ${ }^{94}$ Çünkü böylesi olumsuz bir davranışı ortaya koymak, kalıcı olanı bırakıp geçici olanı tercih etmek anlamına gelecektir. ${ }^{95}$

Diğer taraftan, dünyalık hiçbir menfaatin, kişinin günaha girmesine

${ }^{89} \mathrm{Ra}^{\prime} \mathrm{d} 13 / 26$.

90 Taberî, Câmi'u'l-beyân, 13: 516.

91 Merâğ̂̂, Tefsîru'l-Merâ̆̆̂̀î, 13: 98.

92 Nisâ $4 / 94$.

93 Taberî, Câmi'u'l-beyân, 7: 351.

94 Mevdûdî, Tefhîmü'l-Kur'ân, 1: 392.

95 Beyzâvî, Envâru't-tenzîl, 2: 91. 
sebep olmaması için kazancın ne şekilde elde edildiği de önemli bir husustur. Şirk anlayışının ortadan kaldırıldığı, Müslümanların helal kazanç elde etmeleri için her türlü imkanın sağlandığı Medine döneminde Kur'an, Müslümanların kazançlarını helal bir şekilde temin etmeleri gerektiği hususu üzerinde de durmaktadır. ${ }^{96}$ Mesele, cariyelerin, dünyalık bir çlkar elde etmek uğruna zina etmeye zorlanmasının yasaklanması ${ }^{97}$ bağlamında ele alınmıştır. Bu durum, onların bu işi istekli ya da isteksiz olarak yapmalarına göre değişiklik göstermez. ${ }^{98}$ Dünyalık bir çıkar elde etme uğruna böyle ahlaksız bir fiile yeltenmek dünyanın geçici menfaatlerini ahirete tercih etmek anlamına gelecektir. ${ }^{99}$ Böylesi bir davranış, gayri meşru ve gayri ahlaki olduğu için haram kabul edilmiştir. ${ }^{100} \mathrm{Bu}$ örneklemeden hareketle, aynı haramlığın, içerisinde günahı barındıran bütün kazanç yolları için de geçerli olacağını söylemek mümkün olabilecektir.

\section{Nimeti Verenin Allah Olduğunun Hatırlatılması}

Kur'an ayetleriyle Mekke döneminde zihinlere nakşedilen Allah inancl, Medine döneminde de farklı şekillerde anlatılmaya devam edilmiştir. Ayetlerde, Müslümanların elde ettikleri kazanımların, sadece kendi güçleriyle değil Allah'ın yardımı sayesinde gerçekleştiği, o nedenle de şükür görevinin ihmal edilmemesi gerektiği konusu üzerinde durulmaktadır. ${ }^{101}$

Anlaşılan odur ki, Allah, insanlara, bir insanın kaderini değiștirebilecekleri ya da yardım etmedikleri takdirde herhangi bir kişinin tamamen yardımsız kalacağı şeklindeki anlayışlarının yanlış olduğunu, nimeti asıl verenin kendisi olduğunu hatırlatmıştır. ${ }^{102}$ Çünkü Allah, dünyada ve ahirette kullarına nimet vermeye güç yetiren yegane otoritedir. ${ }^{103}$ Nimet verecek olan Allah olduğuna göre bir kişinin sadece bu dünya nimetleriyle yetinmesi, ahirette mükafat elde etmeyi ihmal etmesi büyük bir hata olacaktır. ${ }^{104}$ Her iki dünya nimetini verenin de Allah olduğu anlaşılınca, kişinin, dünyalık herhangi bir kazanımı, yalnızca kendi güç ve kuvvetiyle elde ettiğini iddia etmesi gerçeğin üzerini örtmek anlamına gelecektir. ${ }^{105}$

Meseleyi Medine dönemi bağlamında düşündüğümüzde, Hz. Ömer'in,

96 Nûr 24/33.

97 Taberî, Câmi'u'l-beyân, 17: 290.

98 Beyzâvî, Envâru't-tenzîl, 4: 106; Râzî, Mefâtîhu'l-gayb, 23: 377.

${ }^{99}$ Merâĝî, Tefsîru'l-Merâğî, 18: 105.

100 Mevdûdî, Tefhîmü'l-Kur'ân, 3: 542.

101 Nisâ 4/134.

102 Mevdûdî, Tefhîmü'l-Kur'ân, 1: 415.

103 Taberî, Câmi'u'l-beyân, 7: 583.

104 Râzî, Mefâtîhu'l-gayb, 11: 240.

105 Merâğî, Tefsîru'l-Merâğîi, 5: 177. 
zaferleri onun komutanlığı sayesinde elde ettiklerini düşündükleri için Halid b. Velid'i görevden alması, Huneyn savaşında Müslümanların, güçlü oldukları halde neredeyse hezimete uğrayacak bir duruma gelmeleri, sonrasında ise zafer elde etmeleri, gerçek yardımın Allah katından olduğu noktasında Müslümanlar için önemli hatırlatmalar olmuştur.

\section{Mekkî ve Medenî Surelerde Dünya Vurgusuyla İlgili Ortak Kullanımlar}

\section{Dünya Hayatının Süslenmiş Olması}

Hem Mekkî hem de Medenî ayetlerde, dünya hayatındaki bazı nesnelerin, Kur'an'ın ifadesiyle insanları kendisiyle çokça meşgul ettirecek derecede güzelleştirilmiş olması, ${ }^{106}$ bu konudaki imtihanın zorluğunu da göstermektedir. Zaten cazibesi olmayan bir şeye insanların meyletmesi de mümkün değildir. Ayette, inkarcıların ve müşriklerin, dünyanın geçici güzelliğini ahiretteki kalıcı güzelliğe tercih etme noktasındaki zaaflarına vurgu yapılmaktadır. ${ }^{107}$ Onlara dünya hayatı güzel gösterilmiş, adeta onu içselleştirmişlerdir. ${ }^{108}$ Orada mal çoğaltmak, diğer insanlara karşı övünmek, yönetici olmak, peygambere tabi olmayı kibirlerinden dolayı reddetmek, Müslümanlarla alay etmek, sahip oldukları imkanlar nedeniyle diğer insanlara üstünlük taslamak dünyanın onların gözünde süslü olmasının bir sonucudur. ${ }^{109} \mathrm{Bu}$ yüzdendir ki, menfaatlerine dokunan her şeyi, bu, din dahi olsa reddetmeyi tercih etmişlerdir. Dünya sevgileri onları, bunun dışındaki her şeyden koparmıştır. ${ }^{110}$

Şunu da bilmek gerekir ki, dünya hayatının, inkarcılar için süslenmiş olması, inanan insanlar için cazibesinin olmadığı anlamına gelmez. İnkarcılar, doğruyu hakikati örtecek derecede kendilerini dünyanın cazibesine kaptırdıkları için dünya hayatının, onların nezdindeki güzelliği daha farklı bir boyutta olmuştur. İnanan insanlar bu güzelliği görmekle birlikte onun arkasındaki gerçek güzelliği, yaratıcının büyüklügünü, ihtişamını onun önüne geçirirler. Ama inkarcılar, meseleyi sadece dünyevi zevkler bağlamında değerlendirirler.

Dünya hayatının süsü dendiğinde ilk akla gelebileceklerin Kur'an'da peşpeşe sıralandığını da görmekteyiz. ${ }^{111}$ Bunlar, her dönemde insanlar için

106 Bakara 2/212.

107 Râzî, Mefâtîhu'l-gayb, 6: 367.

108 Beyzâvî, Envâru't-tenzîl, 1: 135.

109 Taberî, Câmi'u'l-beyân, 3: 619.

110 Merâğ̂̂, Tefsîru'l-Merâğ

111 Âl-i İmrân 3/14; Kehf 18/7. 
cazibesi olabilecek şeylerdir. Bir kısmında şekil yönünden değişimler söz konusu olmakla birlikte bunlar, genel anlamda insanların aşırı düşkün olduğu dünya hayatının güzellikleridir.

Süslenmiş olmaları, imtihan amacına yönelik olduğu gibi ahirette mutluluğu kazanmaya da bir vesile olmasındandır. ${ }^{112}$ İlgili ayet, dünya hayatındaki bu gibi zevklerden fedakarlık yapmayanların her iki dünyada da kaybedeceklerine dair bir uyarı niteliğindedir. ${ }^{113}$ Süslenmiş olmasının, onların zararlı yönleri bilinmesine rağmen onlardan vazgeçilememesi, onlara aşırı bağlanılması anlamına geldiği de söylenmiştir..114 $\mathrm{Bu}$ gibi ayetlerde, dünyada var olan bütün nesnelerin yok olacağı, kalıcı ve hayırlı olanın ahiret olduğu vurgulanmaktadır. Dünyevi lezzetler anlıktır, sonrasında ise insanlara yorgunluğu kalmaktadır. ${ }^{115}$ Ayrıca, dünya hayatını ve yeryüzünde söz sahibi olmayı tercih eden Yahudilere bir uyarı olduğu da söylenmiştir. Bu anlayışlarının bir sonucu olarak, doğru olduğunu bildikleri halde kendi milletlerinden olmayan Hz. Peygamber'e de tabi olmamışlardır. ${ }^{116}$ Her ne kadar konu Yahudiler bağlamında değerlendirilse de ayette zikredilenler, insanların bir ya da birkaçına meylettikleri, vazgeçilmez olarak gördükleri nesnelerdir. Yahudilerin bu noktada dile getirilmiş olması, onların bu konudaki aşırılıklarının diğer milletlerin önüne geçmesindendir.

\section{Dünyanın Övünme Yeri Olması}

Dünyada insanın yiyip-içeceği, kullanacağı nesneler sınırlı olmasına rağmen sadece bu amaç için değil, daha başka gayelerle de dünyalık elde etmeye çalıştıkları görülmektedir. Bunlardan bir tanesi de insanların sahip oldukları maddi ya da manevi konumu diğer insanlara karşı övünmek maksadıyla kullanmalarıdır. Kur'an'daki bazı ayetlerin, ${ }^{117}$ bu gerçeğe işaret ettiği görülmektedir. Böylesi bir anlayıș, dünya görüșlerinin farklı olduğu her toplum için geçerli bir husus olduğu için hem Mekkî hem de Medenî ayetlerde yer almıștır.

Dünya hayatında, insanların sahip olduğu imkanların birbirinden farklı olduğu așikardır. Kimine mal-mülk, kimine mevki-makam, kimine evlat, sağlıklı bir hayat vb. verilmiştir. Ama bu nimetlerden istifade etmenin yanında bazı insanlar, Kur'an'ın anlatımıyla kendilerinde olan bu nimetlerin

112 Beyzâvî, Envâru't-tenzîl, 2: 8.

113 Naml, "Kur'an ve Dünyevileșme ya da Bir Dünya Görüşü Kırılması”, 49.

114 Merâğî, Tefsîru'l-Merâ̆ĝ̀i, 3: 108-109.

|60| 115 Râzî, Mefâtîhu'l-gayb, 7: 159.

116 Taberî, Câmi'u'l-beyân, 5: 253.

117 Hadîd 57/20; Tekâsür 102/1-2. 
olmadığı insanlara karşı bunu bir övünme unsuru olarak görmüşlerdir. İnsanların, sahip oldukları mal-mülk, servet ${ }^{118}$, makam, asalet, yaptığ işler119 ve yaratılışlarıyla, güçleri ve kuvvetleriyle birbirlerine karşı övünmeleri dünya hayatının bir gerçeğidir. ${ }^{120}$ Ama böylesi bir anlayış, cahiliye adetidir. ${ }^{121}$ Ayrıca insanların sahip olduğu imkanlar da farklılıkların olması, dünya üzerinde Allah'ın koymuş olduğu sistemin devamlılığı açısından zaruridir.

Diğer taraftan, verilen nimetlerin çokluğu ile sorumluluk arasında doğru bir orantının olduğu da göz ardı edilmektedir. Her nimet, beraberinde onunla ilgili olarak hesap verileceği gerçeğini hatırlatmaktadır. ${ }^{122} \mathrm{Bu}$ açıdan bakıldığında nimetin çokluğu aynı zamanda bir külfettir. Ayrıca, çoklukla övünmek insanların, ondan daha önemli şeyleri unutmasına da sebep olmuştur. Sahip oldukları imkanları çoğaltmaya çalışmaları, sonrasında kendilerini kibirlenmeye de sevk etmiştir. ${ }^{123}$

İnsanın, imtihan için verilen ömrünü, çoğu zaman, daha faydalı bir şekilde değerlendirmek yerine övünme yarışı içerisinde geçirmesi, ${ }^{124}$ mal ve evlat gibi nimetlere sahip olmasını kendisi için bir ayrıcalık olarak görmesi, kınanan bir davranış olmuştur. ${ }^{125} \mathrm{~Hz}$. Peygamber'in, kıyamet gününde bazı nimetlere mazhar olacağını ifade ettikten sonra "övünmek yok" ifadesini kullanması ${ }^{126}$ da böylesi bir davranışın doğru olmadığının göstergesidir.

\section{Oyun ve Eğlence Mekanı Olarak Dünya}

Dünyanın oyun ve eğlence yeri olduğunu ifade eden ayetlerde, ${ }^{127}$ mesele ahirete hazırlı anlamı taşımayan zevkler bağlamında düşünüldüğünde bunların oyun ve eğlence olarak değerlendirildiğini görmekteyiz. Elbette ki, oyun ve eğlence olması bunların tümünün haram olduğu anlamına da gelmeyecektir. Buna karşın, göklerin ve yerin oyun ve eğlence için yaratılmadığını ifade eden ayetlerin var olduğu da bir

118 Taberî, Câmiu'l-beyân, 22: 416.

119 Muhammed Seyyid Tantâvî, et-Tefsiru'l-vasit li'l-Kur'an'il-Kerim (Kahire: Daru Nehda, 1998), 14: 219.

120 Şevkânî, Fethu'l-Kadir), 5: 209.

121 Seâlibî, el-Cevahiru'l-hisan, 5: 389.

122 Tekâsür 102/8.

123 Mevdûdî, Tefhîmü'l-Kur'ân, 7: 220.

124 İmadu'd-Din Ebu'l-Fidâ İsmail İbn Kesîr, Tefsîru'l-Kur'âni'l-Azîm (Byy: Müessesetü Kurtuba, 2000), 13: 428.

125 Mustafa Fayda, "Ensâb”, Türkiye Diyanet Vakfı İslâm Ansiklopedisi, c. 11 (İstanbul: TDV Yay., 1995), 245.

126 Tirmizî, Menâkıb, 1.

127 Ankebût 29/64; En'âm 6/32; Muhammed 47/36; Hadîd 57/20. 
gerçektir. ${ }^{128}$ Burada kast edilen durumun ise, insanın, gayesiz bir şekilde yaratılmış olmayıp, dünyaya imtihan için gönderildiğine işaret amacı taşıdığını söyleyebiliriz.

Dünya hayatının oyun ve eğlenceye benzetilmesi, daha çok ahiretle kıyaslanmak suretiyle ortaya konan bir vurgudur. Çünkü ahiret hayatının dünya hayatına bir üstünlüğü vardır. ${ }^{129}$ Dünyadaki eğlenceler, ahiretteki nimetlere göre çok daha kısa sürelidir. ${ }^{130}$ Dünya hayatındaki lezzetler, bazı acıları gidermek, örneğin açlığın acısını gidermek için yemek yemek, susuzluğun acısını gidermek için su içmek ${ }^{131}$ kabilinden şeylerdir. Ayrıca gereksiz gurura da sebep olabilmektedir. ${ }^{132}$ İnkarcılar, ahiret hayatı için hazırlık yapmak yerine hayatı bu dünyadan ibaret görüp zamanlarını dünya nimetleriyle geçirmektedirler. ${ }^{133}$ Oysa dünya hayatı fani, geçici oluşu nedeniyle oyun ve eğlenceye benzetilmiştir. ${ }^{134}$ Diğer taraftan, kalıcı olan ahiret nimetlerini elde etmeye vesile olacak salih amelden insanı alıkoyan dünyalık meşguliyetlerin oyun ve eğlenceye benzetildiği 135 de söylenmiştir. Burada inkarcılar, dünya hayatının zevklerini, eğlencelerini, ahiretin önüne geçirdikleri için eleştirilmektedirler. ${ }^{136}$ Tabii ki bu davranışları, zaman zaman inanan insanlarda da görmek mümkündür. İlgili ayetlerde, inkar edenlerin, bu şekilde ahlaki zaaflarıyla zikredilmiş olması, müminlere de bir uyarı mahiyetindedir. $\mathrm{Bu}$, olumsuz örneği anlatıp olumlu bir kişiliğe büründürme öğretisidir.

Diyebiliriz ki, dünya nimetleri, ahiret nimetleriyle hem süre hem de güzellik açısından kıyaslanınca basit bir oyun ve eğlence gibidir. ${ }^{137}$ Dünyanın oyun ve eğlenceye benzetilmesine daha farklı açllardan yaklaşımların olduğunu da görmekteyiz. Bu bağlamda ahirette yeni bir hayatın, mükafat ve cezanın olacağını kabul etmemek oyun ve eğlence olarak adlandırılmıştır. ${ }^{138}$

\footnotetext{
128 Enbiyâ 21/16.

129 İbn Kesîr, Tefsîru'l-Kur'âni'l-Azîm, 6: 25.

130 Fahruddin er-Râzî, Mefatîhu'l-gayb-et-tefsiru'l-kebir (Beyrut: Daru İhyai't-Turasi'lArabiyyi, 3. baskı, 1422), $12: 515$.

131 Merâğî, Tefsîru'l-Merâğ̂̀, 7: 107.

${ }^{132}$ Ahmed b. Muhammed b. İbrahim es-Sa'libî, el-Keșf ve'l-beyân an tefsiri'l-Kur'an (Beyrut: Daru İhyai't-Turasi'l-Arabiyyi, 1422/2002), 4: 144.

133 Tantâvî, et-Tefsiru'l-vasit, 5: 64.

134 Sevkânî, Fethu'l-kadir, 2: 458.

135 Beyzâvî, Envâru't-tenzîl, 2: 159.

136 Şihâbuddîn Mahmûd b. Abdullah el-Hüseynî el-Âlûsî, Ruhu'l-meanî fi tefsiri'l-Kur'an ve's-sebu'l-mesânî (Beyrut: Daru'l-Kütüb el-İlmiyye, 1415), 4: 126.

137 Ebu'l-Kâsım Mahmûd b. Amr b. Ahmed ez-Zemahşerî Cârullah, el-Keşşaf an hakaiki gavamizi't-tenzil (Beyrut: Daru'l-Kitab el Arabiyyi, 3. baskı, 1407), 2: 17.

138 Muhammed b. Muhammed b. Mahmud Ebu Mansur el-Mâturîdî, Tefsiru'l-Maturidî (Te'vîlâtü Ehli's-Sünne) (Beyrut: Daru'l-Kütüb el-İlmiyye, 1426/2005), 4: 69.
} 
Yine faydalı olanı bırakıp faydasız olanı tercih etmek, ciddi olanı bırakıp şaka gibi olanı tercih etmek oyun ve eğlence olarak nitelendirilmiştir. ${ }^{139}$ Kalıcı lezzetlere götüren iman etmekten, salih amel işlemekten alıkoyan bütün dünyalık lezzetler oyun ve eğlencedir ${ }^{140}$ de denilmiştir. Cuma suresinin son ayetinde, namazı bırakıp dünyalık şeyler elde etmeye koşanların eleştirilmiş olmasını bu çerçevede değerlendirmek mümkündür. Salih amel dışındaki bütün dünyalık meşgaleler de yine oyun ve eğlence olarak tabir edilmiştir. ${ }^{141}$

Kur'an'da, dünya hakkında böyle bir ifadenin kullanılmış olmasını, o günkü Arap toplumunda dünyanın gerçek hayat alanı olarak algılanması nedeniyle ondan en üst düzeyde haz alma amacına matuf olduğu da ${ }^{142}$ söylenmiştir. Aynı anlayışın günümüzde de var olduğunu, hayat, bu dünyadan ibaretmiş gibi algılanmasa da dünyevi yaşantının en üst düzeyde zevk alma şeklinde birçok insanda tezahür ettiğini görmek de mümkündür. Bunun en tehlikeli yanı, insana kulluğunu, ibadet hayatını unutturacak boyuta ulaşmasıdır. Dünyevi zevklere dalmak, bağımlılık boyutuna ulaştığında ise, haram olsa dahi onları elde etmek kişi için kaçınılmak hale gelecektir.

\section{Dünya Hayatının Fâniliği}

Dünyayı bir imtihan yeri olarak düşündügümüzde, imtihan bittiğinde imtihan alanının varlık gayesi de sona ermiş olacaktır. Geçici zevkler bağlamında düşündüğümüzde de dünyevî zevklerin hiçbirisi kalıcı olmayacağından bir gün mutlaka sona erecektir. Kur'an'a göre Allah, sadece üstün varlık değil, var denmeye layık tek gerçek varlıktır. Varlık dünyasının merkezinde Allah vardır. ${ }^{143}$ Bunun aksine son bulacak olan dünya nimetleri için varlık geçici bir hüviyete sahiptir. Ayetlerde dünya hayatının geçici olduğunun vurgulanması, ${ }^{144}$ ona olan bağlılığın ölçülü olması gerektiği gerçeğini hatırlatmaktadır.

Ayetlerde anlatılmak istenen, dünyanın, insanların kısa bir süre faydalanacağı, daha sonra yok olup gidecek bir yer olmasıdır. ${ }^{145}$ İnsan, bu

139 Ebu'l-Berekat Abdullah b. Ahmed b. Mahmud Hafızuddin en-Nesefî, Medârikü't-tenzîl ve Hakaiku't-Tevil (Beyrut: Daru'l-Kelime't-Tayyib, 1419/1998), 1: 500.

140 İsmail Hakkı Bursevî, Rûhu'l-beyân fî tefsîri'l-Kur'ân (Beyrut: Daru İhyai't-Turasi'lArabiyyi, ts), 3: 18 .

141 Ebu'l-Hasan Ali b. Muhammed b. Muhammed b. Habib el-Basrî el-Bağdadî eș-Șehir bi'lMâverdî, en-Nüket ve'l-uyûn (Beyrut: Daru'l-Kütüb el İlmiyye, ts), 2: 106.

142 Öztürk, "Kur'an'ın Değer Sisteminde Dünya ve Dünyevi Hayatın Anlamı”, 68.

143 İzutsu, Kur'an'da Allah ve Insan, 69.

144 Âl-i İmran 3/185; Nisâ 4/77; Yûnus 10/23; Kehf 18/46; Mü’min 40/39; Kasas 28/60, 61; Şûrâ 42/36; Duhân 44/25-28.

145 Kurtubî, el-Câmi'u li ahkâmi'l-Kur'ân, 18: 361. 
dünyada geçici bir süre oyalanır, onun nimetlerinden istifade eder. Sonrasında ise sonsuz bir hayata doğru yelken açar. ${ }^{146} \mathrm{Bu}$ açıdan bakıldığında dünya hayatı ahirete kıyasla az bir süreden ibarettir. Ahiretteki güzelliklerin özlemiyle yaşayan mümin için burada kalmak bir eziyet gibidir. İnkarcı için ise vazgeçilmez bir güzelliktir: "Dünya, mümine hapishane; inkarcıya cennettir." 147 Akıllı olan bir insan için ise devamlı olan, geçici olandan daha hayırlı olacaktır. ${ }^{148} \mathrm{~Hz}$. Peygamber, insanın, kısa ömürlü olmasına rağmen uzun yaşama arzusunu ve dünyaya bağlılığını yere bazı şekiller çizerek anlatmıştır ki, ${ }^{149}$ bu durum insanların, kulluk görevini hakkıyla yerine getiriyor ve ahiret hakkında gerekli hazırlığı yapıyor olsalar dahi bu dünyada daha uzun yaşamayı arzu edeceklerinin göstergesidir. ${ }^{150} \mathrm{Bu}$ arzunun, insanda fitri olarak var edilen bir özellik olduğunu söylemek mümkündür.

Biliyoruz ki, ahirette mutluluğu elde edebilmek için dünya hayatında çok yaşamak değil, kısıtlı süreyi iyi değerlendirmek akıllıca bir hareket olacaktır. ${ }^{151}$ Asır suresinin ilk ayetinde zamana yemin edilmiş olması, dünya hayatında vaktin kıymetini hatırlatmaktadır. Sonuçta dünya ödül verilen bir yer değil, imtihan için farklı firsatların kişilere sunulduğu mekandır. ${ }^{152}$ İmtihan bir amaç değil araçtır. Süresi de gayesi açısından düşünüldügünde daha kısa olacaktır. Hem dünyaya gönderilen insanın kısa ömrü hem de Allah'ın büyüklügü, kainat ve onun ötesi, dünyanın var olduğu zaman dilimi ve diğer dönemler açısından düşünüldüğünde dünyanın ömrünün çok kısa olduğu görülmektedir.

\section{Dünya Malına ve Evlatlarına İmrenilmemesi Gerektiği}

Müslümanların, sahip oldukları imkanlarla yetinip kanaatkar olmaları, olmayanlara isyan etmek yerine olanlara şükretmeleri, başkalarında var olan nimetleri kıskanmak suretiyle kendilerini yıpratmamaları, dünyaya daha önemli bir amaç için gönderildikleri hatırlatılmak suretiyle asıl ona odaklanmaları Kur'an'ın üzerinde durduğu 153 önemli hususlardandır.

Özellikle inkarcılara verilen mal ve evlatlar, onların doğru yol üzere

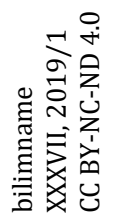

$|64|$

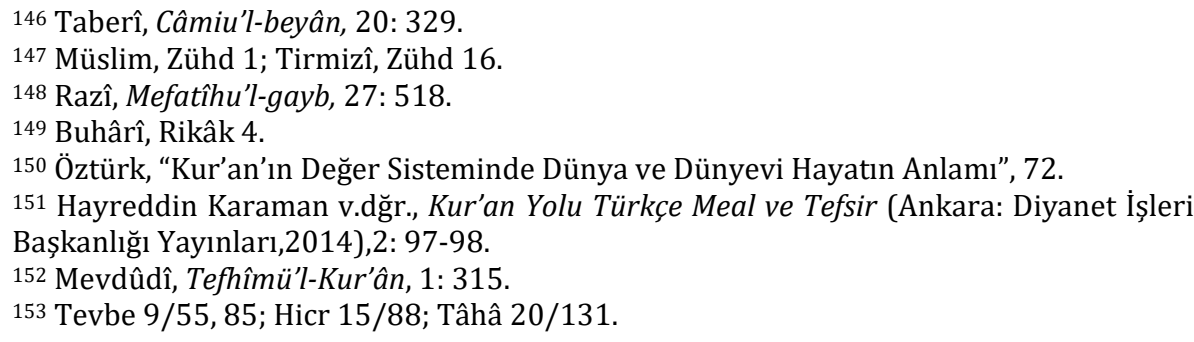


oldukları anlamına gelmediği gibi onlar için ayrı bir sorumluluk anlamı taşımaktadır. ${ }^{154}$ Zaten dünyalık mal ya da evlat gibi nimetlerin cazibesine kapılmak suretiyle onları hayatın merkezine yerleştirmek, onların mutlaka hayır getireceğini ummak, bunları diğer insanlara karşı kibirlenme aracı gibi görmek Kur'an'ın öngörmediği bir davranış tarzıdır. ${ }^{155} \mathrm{Bu}$ ikisi büyük nimetler olmasına rağmen onları kazanmak, koruyup gözetmek, sıkıntılarına katlanmak insan için aynı zamanda büyük bir zorluktur. ${ }^{156}$ Ayrıca bu imkanlar, her ne kadar faydalı gibi gözükse de, iyi değerlendirilmediği takdirde kişinin Müslümanca yaşamasına, onurunu ve itibarını korumasına engel teşkil edebilecek bir duruma da gelebilmektedir. ${ }^{157}$

Öte yandan, mal ve evlatların Kur'an'da, dünyanın süsü158 ve imtihan sebebi (fitne) ${ }^{159}$ olarak nitelendirilmesi, sahip olduğu mal ve evlatları koruma uğruna dünyayı imar etmeyi terk etmenin anlamsızlığını, çünkü böyle bir durumda dünyaya Müslüman olmayan şeytani unsurların egemen olacağını vurgulamaktadır. ${ }^{160}$ Dünyevî olana karşı aşırı istek ve aileyi koruma arzusu kişiyi ilahi mesajı ötelemeye ve ahlaki değerleri göz ardı etmeye de sevk edebilmektedir. ${ }^{161}$ Zaten Kur'an'da eleștirilen dünya hayatı, kısa vadeli menfaatler uğruna büyük ideallerden vazgeçmek, toplumsal mücadeleye katılıp müminlerin dünyaya egemen olmasına katkıda bulunmak yerine kişisel çıkarlarının peşinden koşmaktır. ${ }^{162}$ Çünkü kişinin cihad etmesine, zamanını daha büyük hedefler için kullanmasına çoğu zaman ailesi ve sahip olduğu malının zarar görmesi endişesi engel olmaktadır.

\section{Dünya'nın Bir İmtihan sahası Olması ve İman Etme Sorumluluğu}

Dünyanın imtihan yeri olması, Mekkî ve Medenî surelerde üzerinde durulan önemli hususlardandır. ${ }^{163} \mathrm{Bu}$ konu Mekke döneminde, insanların dünyaya, Allah'ı tevhid inancı ekseninde kabul etmelerinin sağlanması, Medine'de ise dünyevî meşguliyetlerin, kulun imtihan için gönderildiği dünyada bu amaca engel olmasının engellenmesi bağlamında değerlendirilmiştir.

\footnotetext{
154 Beyzâvî, Envâru't-tenzîl, 3: 85.

155 Râzî, Mefâtîhu'l-gayb, 16: 71.

156 Merâĝ̀i, Tefsîru'l-Merâğî, 10: 137-138.

157 Mevdûdî, Tefhîmü'l-Kur'ân, 2: 237.

158 Kehf 18/46.

159 Enfâl 8/28; Tegâbün 64/15.

160 Namll, "Kur'an ve Dünyevileșme ya da Bir Dünya Görüşü Kırılması”, 48.

161 Öztürk, "Kur'an'ın Değer Sisteminde Dünya ve Dünyevi Hayatın Anlamı”, 71.

162 Namll, "Kur'an ve Dünyevileșme ya da Bir Dünya Görüșü Kırılması", 47.

163 Ankebût 29/2-3; Ra'd 13/26; Tâhâ 20/131; Mülk 67/2; Bakara 2/155
} 
Bu imtihanı Mekke şartlarında düşündügümüzde Müslüman olan kişiler, madden ve manen büyük bir imtihandan geçmekteydiler. Ekonomik anlamda ambargoya, toplumsal anlamda baskiya ve korkuya maruz bırakılmaktaydılar. Medine döneminde de örneğin Uhud savaşından sonra Müslümanlar, bir üzüntü dönemi geçirmişlerdi. ${ }^{164}$ Bunların her biri onların imanlarındaki sebatın görülmesi açısından büyük imtihanlardı. Biliyoruz ki, imtihandan kasıt, dünyada işlenen amellerle göre ahirette karşllık verilmesidir. Eğer ki imtihan olmasaydı, Allah'ın dinini yüceltmek adına birçok sıkıntıya katlanan Müslümanlarla, o dini yıkmak için çaba sarf eden inkarcılar arasında bir fark olmazdı. ${ }^{165} \mathrm{Bu}$ durum, inkarcılar için bir avantaja dönüşürdü. Bu imtihan sürecinde Allah'ın davetine icabet, hatalardan ve özellikle büyük günahlardan uzak durma, iyi ameller işlemenin yanında bunlarda samimiyet unsuru da göz ardı edilmemesi gereken bir hakikattir. ${ }^{166}$ Yine bu süreçte sabrı ve şükrü ölçme vardır ki insanlar yaptıklarına göre ahirette muamele görsünler ${ }^{167}$ ve bu dünyada tam olarak sağlanamayan adalet tecelli etmiş olsun.

Diğer taraftan yukarıda verdiğimiz ve imtihandan bahseden ayetlerde hayatın ve ölümün imtihan için olduğunun zikredilmesi dikkat çekicidir. Ölüm, insanlara hayatlarındaki sorumluluğu hatırlatması açısından, hayat ise hayırlı faaliyetler yapmak için var edilmiş bir imtihan yeri olması açısından dile getirilmiştir ${ }^{168} \mathrm{ki}$ insanlar her ikisini de imtihanın mahiyeti açısından iyi idrak edip ona göre gerekli hazırlıklarını yapsınlar.

İmtihan için gönderilmenin ön şartı gönderene ve gönderdiklerine iman etmektir. Bu olmadan imtihanın başarıya ulaşması mümkün değildir. Mekke döneminde bu durum insanların iman etmelerini sağlama, Medine'de ise daha çok bu imanda sebat etmelerini, imanlarına zarar verebilecek unsurlardan kendilerini temizlemelerini sağlama amacına yönelikti. İlgili ayetler ${ }^{169}$ de zaten bu minval üzere gelmişti.

İman etmeden hiçbir amelin kıymeti olmadığı gibi, emir ve yasaklara riayet etmeden de iman tek başına yeterli olmayacaktır. Kulluğun hakkı da zaten farzları yerine getirmek ve yasaklanan şeylerden uzaklaşmakla yerine getirilmiş olur. ${ }^{170}$ Allah'ın kullardan istediği şey, putları terk edip tevhid

\footnotetext{
164 Mevdûdî, Tefhîmü'l-Kur'ân, 4: 223-224.

165 Elmalılı, Hak Dini Kur'an Dili, 9: 179.

166 Merâğ̂̂, Tefsîru'l-Merâğ $̂$ i, 29: 5-6.

167 Kurtubî, el-Câmi'u li ahkâmi'l-Kur'ân, 21: 112.

168 Karaman v.dğr., Kur'an Yolu Türkçe Meal ve Tefsir, 5: 417.

169 Ra'd 13/29; Muhammed 47/36; Zümer 39/10.

170 Merâğ̂̀, Tefsîru'l-Merâğîi, 26: 78.
} 
anlayışına sahip olmak ve emir ve yasaklarına riayet etmektir. ${ }^{171}$ İnsanlar, iman edip takva sahibi olduklarında yine kendileri kârlı çıkacak ve cenneti kazanacaklardır. ${ }^{172}$ İman etmekten kasıt ise Allah ve Resulüne iman edip şirkten sakınmaktır. ${ }^{173}$ Bunun yanında küfür ve isyan anlamına gelebilecek her türlü davranışı terk etmek ${ }^{174}$ de imanın sağlam ve güçlü olabilmesi için zorunlu bir etkendir. Kur'an, insanlara sadece iman etmelerini söylemez, insanların iman etmesi için ikna edici deliller de kullanır. İman edenlere ortaya koydukları fedakarca tutumları nedeniyle dünyada da ahirette de güzellikler olacağını müjdeler. ${ }^{175}$ Buna rağmen bazı insanların böylesi bir sağlam kaynağı ve kuvvetli delilleri kabul etmeyerek başka etkenlerle, inkar etmeleri, başıboş bir hayat yaşamaları aklen de doğru bir davranış tarzı olamaz.

\section{Dünyanın Güzelliklerini İnanan İnsanların Hak Ediyor Olması}

İnsanların iman etmelerinin ne kadar önemli olduğunu ortaya koymak adına imanın, hem Mekkî hem de Medenî surelerde ${ }^{176}$ anlatıldığı üzere, bu dünyada da getirisinin olduğu dile getirilen hususlardandır. 0 da dünyevî nimetleri, onları verene iman edenlerin hak ediyor olmasıdır.

Her ne kadar dünya nimetlerinden, çalışıp kazanan herkesin istifade etmesi mümkün ise de onu asıl hak eden, o nimetleri verene iyi bir kul olmaya çalışarak şükür görevini yerine getiren inanan insanlardır. Ayetlerde yer alan ifadelerden anlıyoruz ki, İslam dini, inananlarına hem dünya hem de ahiret saadetini vaad ettiği için onlar dünyadaki nimetleri de en çok hak edenlerdir. ${ }^{177}$ Temiz olan yiyecekler, kalplerini ibadetle temizleyenler içindir. ${ }^{178}$ Çünkü bu nimetler aslında inananlar için yaratılmış, ${ }^{179}$ inkarcılar ise onlara ait olan bu nimetlere ortak olmuşlardır. ${ }^{180}$ Ayrıca müminler, bu nimetlerden dünya hayatında istifade etmenin yanında ahirete de azık hazırlamaya çalışır ve onların bir imtihan sebebi olduğunu bilir. Ona göre de

\footnotetext{
171 Kasımî, Mehâsînü't-tevîl, 13: 479.

172 Ali b. Muhammed Hazîn, Lübâbü't-tevîl fî me'âni't-tenzîl (Beyrut: Daru'l-Kütüb elİlmiyye, 1415), 9: 150.

173 Nesefî, Medârikü't-tenzîl, 3: 331.

174 Şevkanî, Fethu'l-kadir, 5: 50.

175 Mevdûdî, Tefhîmü'l-Kur'ân, 5: 102.

176 "Ey insanlar! Yeryüzünde bulunanların helâl ve temiz olanlarından yeyin..." Bakara 2/168. Ayrica bkz. A'râf 7/32.

177 Merâĝ̀̂, Tefsîru'l-Merâğî, 8: 136.

178 Muhammed cemaluddin b. Muhammed Said b. Kasım el-Hallak el-Kâsımî, Mehâsînü'ttevîl (Beyrut: Daru'l-Kütüb el-İlmiyye, 1418), 5: 46.

179 Razî, Mefatîhu'l-Gayb, 14: 231; Zemahșerî, a.g.e, II, 101.

180 Beyzâvî, Envâru't-tenzîl, 3: 11.
}

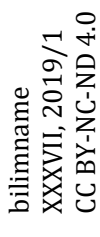


onlardan istifade etmeye çalışır, çalışmalıdır.

Kur'an'ın mal ve servet biriktirme konusundaki eleştirisi, onun kötüye kullanılması nedeniyle yüce ahlaki değerleri elde etmeye engel olması ihtimalinden dolayıdır. ${ }^{181} \mathrm{Bu}$ nedenle Allah'ın insanlara vermiş olduğu nimetlerden istifade etme noktasında, cahiliye adetlerinin bir kalıntısı olarak insanların koymuş olduğu gereksiz engellemelerin ortadan kaldırılması gerekmektedir. ${ }^{182}$ İnsanların, kendi anlayıșlarına göre delile dayanmadan helal-haram kriterleri belirlemeleri ve de insanları bunlara uymaya zorlamaları Kur'anî bir bakış açısı olmayacaktır.

\section{Dünya-Ahiret Denklemi}

Hem Mekkî hem de Medenî surelerde ${ }^{183}$ insanların dünya ya da ahiretten birini seçmeye zorlanmadıkları, bu konuda özgür bırakıldıkları, hangisini isterlerse kendilerine onun verileceği hususunun hatırlatıldığını görmekteyiz. Ne var ki, istemek, sadece dil ile bunu ifade etmek değil, onun için çaba ortaya koymak anlamına gelecektir.

Allah, insana irade hürriyeti vermiştir. Bunun sonucunda $o$, seçimlerini, bu özgür iradesine göre yapacaktır. Dünyanın imtihan sahası olması bunu gerektirmektedir. Ayetlerde kişinin bu tercihine vurgu yapılmakta ve akibetini kendisinin hazırladığı üzerinde durulmaktadır. İlgili ayetlerde kast edilen, dünya nimetlerinin haram olduğu değil, sadece dünyayı isteyip ahiret için hazırlık yapmamaktır. ${ }^{184}$ Ayrıca helal haram ayrımı yapmadan mal biriktirmek ve onu sadece kendi zevki için kullanarak ihtiyaç sahiplerine yardım etmemek de yanlış bir davranış olarak görülmektedir. ${ }^{185}$ Ahireti isteyenlerin, dünya nimetlerinden istifade etmelerinin önünde bir engel yoktur. ${ }^{186}$ Helalinden kazanarak, israf etmeden ve ihtiyaç sahiplerine hakkını verdikten sonra helal olan nimetlerden istifade etmek mümkündür.

Öte yandan, ahireti istemekten kastın dünyada Allah'ın kelimesini yüceltmeye çalışmak ve ahirette yüksek dereceler elde etmeyi istemek, ${ }^{187}$ olduğu da söylenmiştir. Hadislerde de ahireti ihmal edip sadece dünyaya yönelenin dünyada da sıkıntı çekeceği, ahirete öncelik verenin dünyadaki

\footnotetext{
181 Öztürk, “Kur’an'ın Değer Sisteminde Dünya ve Dünyevi Hayatın Anlamı”, 71.

182 Mevdûdî, Tefhîmü'l-Kur'ân, 1: 135.

183 Bakara 2/200-201; Âl-i İmrân 3/145; Hûd 11/15; Şûrâ 42/20.

184 İbn Așûr, et-Tahrir ve't-tenvir, 4: 15.

185 Merâğî, Tefsîru'l-Merâğ̂̂i, 4: 91.

186 İbn Atlyye el-Muharraru'l-vecîz, I: 518.

187 Nesefî, Medârikü't-tenzîl, 1: 298.
} 
işinin de kolaylaştırılacağı ifade edilmektedir. ${ }^{188}$ Ahirete öncelik verilmiş olması, dünyayı ihmal etmek ve onun nimetlerinden uzak durmak anlamına gelmeyecektir. Ama dünyalık nimetleri hiçbir ayrım yapmadan ve helalharam demeden istemek kişiyi, dünyanın kulu kölesi haline getirecektir. Böylesi anlayışa sahip olan kişilerin ahireti ihmal etmesi kaçınılmazdır. ${ }^{189}$ Bunun yerine her ikisinden de istifade etmek ve nasibini aramak tercih edilen davranış modelidir.

Kur'an'ın bu noktada öngördügü davranış tarzı her ikisinin birlikte istenmesidir. ${ }^{190}$ Dünya ya da ahiretten birinin ihmal edilmesi, ilahi davanın ruhuna aykırı bir husustur. Dünyanın ihmal edilmesi, İslam'ın yeryüzüne hakim olmasına ve inanan insanların haksızlıklara maruz kalmasına sebep olabileceği gibi ahiretin ihmal edilmesi de Allah'a olan kulluğun yerine getirilmemesi ve dünyada yapılan haksızlıkların, kul hakkına riayetsizliğin çoğalması anlamına gelecektir. Dünya ve ahireti isteyen ve onlar için çalışanlara her ikisinin de verileceği yine Kur'an'da hatırlatılmaktadır. ${ }^{191} \mathrm{Bu}$, inanan insanın dünyayı ve ahireti anlama ve algılama tarzını yansıtmaktadır.

Dünyayı ebedî sanma yanılgısına kapılmadan ve de bireyselliği, toplumsal sorumlulukların önüne geçirmeden, ahiretle birlikte dünyevî nimetleri de istemenin sakıncası olamaz. ${ }^{192}$ Zaten insan, hem bu dünyada hem de ahirette zayıf bir yapıda yaratılmış olduğundan her zaman Allah'ın yardım ve desteğine muhtaçtır. 0 nedenle her iki dünyada da O'ndan yardım istemek durumundadır. ${ }^{193}$ Dünya hayatında iyilik istemek, sebeplere sarılmak, kazanç elde etmek için çalışmak, hayatını düzene sokmak, insanlarla iyi ilişkiler kurmak, güzel ahlaklı olmak, örfün güzelliklerinden istifade etmekle gerçekleşir. Ahireti istemek ise, iman, ihlas, salih amel ve güzel ahlakla hayat bulur. ${ }^{194}$ Dünyada verilecek nimetin ilim, mal, beden sağlığı, güzel geçim, ve ibadet, ahirette verilecek olanın ise azaptan korunmak ve cennet olacağı söylenmiştir. ${ }^{195}$ Her ikisinin birlikte istenmesi, aralarında tam bir dengenin olduğu anlamına gelmez. Ahiret mutlak anlamda dünyadan daha üstündür. ${ }^{196}$ Ayrıca dünyalık bir şey elde etmek için ortaya konan çaba bazen o nimetlerden alınan hazzı gölgede bırakmaktadır. Ama

188 İbn Mâce, "Zühd”, 1; Tirmizî, "Kıyâmet”, 31.

189 Karaman v.dğr., Kur'an Yolu Türkçe Meal ve Tefsir, 1: 318-319.

190Bakara 2/201; A'râf 7/156.

191 Yûnus 10/64.

192 Namll, "Kur'an ve Dünyevileșme ya da Bir Dünya Görüșü Kırılması", 49.

193 Râzî, Mefâtîhu'l-gayb, 5: 336.

194 Merâğ̂̂, Tefsîru'l-Merâğ̂̀, 2: 106.

195 Taberî, Câmi'u'l-beyân, 3: 547.

196 Öztürk, “Kur'an’ın Değer Sisteminde Dünya ve Dünyevi Hayatın Anlamı”, 78. 
ahirette herhangi bir çaba ve yorgunluk olmayacağından oradaki nimetler insana daha büyük bir zevk verecektir.

Her ne kadar dünya-ahiret denkleminde insanlara tercih hakkı verilmiş olsa da ahiretin öncelenmesine Kur'an'ın vurgu yaptığı da bir gerçektir. ${ }^{197} \mathrm{Bu}$ durum daha çok, ikisini birlikte gerçekleştirme imkanı olmadığı durumlarda geçerlidir. Ya da zamanın daha büyük bir kısmının ahiret için hazırlığa ayrılması șeklinde düşünülebilir.

İnsan, hayatı boyunca bir tercihte bulunur ve ona göre hayatını dizayn eder. Tercihlerden birisi, dünyadaki nasibini unutmadan ahiret hayatına öncelik vermesi ve ona hazırlık yaparak yaşaması; diğeri ise hayatı sadece bu dünyadan ibaret görüp, hayatını ona göre şekillendirmesidir. Hayatı bu dünyadan ibaret görüp, yaratıcısını tanımayan anlayış, dünyaya gönderiliş gayesine ihanet eden sapkın zihniyetin ürünüdür. $\mathrm{Bu}$ açıdan azgınlık (tuğyan), insanı Allah'a kulluktan alıkoyan en önemli etkendir. ${ }^{198}$ Ahireti yalanlayan, ${ }^{199}$ ona hazırlık yapmayan, ${ }^{200}$ inatçlık yaparak dünya hayatını ahirete tercih edenlerin gideceği yer ise ateștir. ${ }^{201}$ Dünya hayatının güzelliklerinden helal olmak kaydıyla istifade etmede bir sakınca yokken, haddi aşıp günaha düşen kişinin ahirette nasibi olmayacaktır. ${ }^{202}$

Ecelin ötesinde bir şey görmeyen cahiliyenin aksine Kur'an, gerçek ve ebedi hayatı görür ${ }^{203}$ ve ona hazırlık yapılmasını ister. $\mathrm{Bu}$ açıldan bakıldığında, dünya hayatının ahirete öncelenmesinin, inkarcı zihniyetin ürünü olduğu gözükmektedir. Ahireti önceleyenler, uzun vadeli düşünen, iman ve ümitle yaşayan insanlar oldukları için kaybetme riskleri yoktur. ${ }^{204}$ Öte yandan insanın, dünya ve ahiret tercihinde sevgi unsuru ön plana çıkmaktadır. Dünyayı tercih edenler, onu ve nimetlerini sevmede aşırıya gidenlerdir. ${ }^{205} \mathrm{Bu}$ aşırı sevgi onların gözünü kör etmiş ve ötesini göremez hale gelmişlerdir. Önlerinde bulunan hazır nimeti, kendilerine vaad edilene tercih etmișlerdir.

Hem dünya hem de ahiret Allah'a ait olduğuna göre, ${ }^{206}$ bir mümin için

\footnotetext{
197 Tevbe 9/38; İbrâhîm 14/3; Kehf 18/28; Nahl 16/107; Nûr 24/37; Nâziât 79/37-39.

198 İbn Aşur, et-Tahrir ve't-tenvir, 30: 91.

199 Seâlibî, el-Cevahiru'l-hisan, 5: 550.

200 Şevkanî, Fethu'l-Kadir, 5: 459.

201 İbn Kesîr, Tefsîru'l-Kur'âni'l-Azîm, 14: 245.

202 Maturidî, Te'vîlâtü Ehli's-Sünne, 10: 414.

203 İzutsu, Kur'an'da Allah ve İnsan, 124

204 Naml, "Kur'an ve Dünyevileșme ya da Bir Dünya Görüșü Kırılması", 50.

205 Karaman v.dğr., Kur'an Yolu Türkçe Meal ve Tefsir, 3: 302.

206 Necm 53/25.
} 
her ikisi hakkında en doğru değerlendirmeyi Allah yapacaktır. ${ }^{207}$ Yapılan her işin bir karşılığı olacağından dolayı kişinin dünya ya da ahiret algısı ve bunun pratik hayata yansıtılması, onun ahlaki tavrını da belirlemiş olacaktır. ${ }^{208}$ Müminin dünya hayatına bakışı, ondan helal olmak kaydıyla istifade etmek, zamanını iyi değerlendirmek, bu esnada dünyaya gönderiliş gayesini ihmal etmeyecek tarzda bir hayat sürmektir.

Onların, ahireti yok sayan bu sapkın anlayışlarına karşılık Allah, dünyevî yaşantıyı yok saymaksızın, ahireti de hayatın bir parçası olarak görmeyi, birini ihmal etmeksizin her ikisine yönelik çalışma ortaya koymayl emrediyordu. ${ }^{209}$ Diğer bir deyişle, Yahudiler gibi dünyevîleşmeyi de Hıristiyanlar gibi dünyadan tamamen kopmayı da reddeden bir anlayışı öngörüyordu. Gerçi bugün Hıristiyan dünyası da kendi dini anlayışlarından kopup Yahudileşme temayülü gösteren bir konuma gelmişlerdir.

Dünya ile ahiret arasında herhangi bir çelişkiden bahsetmek yerine diyalektik bir ilişkiden bahsetmek daha doğru olacaktır. ${ }^{210}$ Ayetlerden anlaşılan husus da zaten, insanın, dünyada iken ömrünü günaha dalarak zayi etmeyip, ahireti kazandıracak salih ameller işlemesi, helalinden olmak ve israf etmemek kaydıyla dünyanın nimetlerinden istifade etmesi temeline dayalıdır. ${ }^{211}$ Dünya nimetlerinden istifade etmekle birlikte bu nimetlerin, insanı salih amel işlemekten ve ahirete hazırlık yapmaktan alıkoyabileceği ve hatta kişiyi inkara götürebileceği hususunda da insanlar uyarılmaktadırlar. ${ }^{212} \mathrm{Bu}$ nedenle infak etme, imkanlarını başkalarıyla paylaşma, böyle bir zararı önleme noktasında atılacak önemli bir adımdır. ${ }^{213}$ Dünyevi nimetler içerisinde kaybolmadan onları, ahiret için bir hazırlık aracı gibi görüp infak etmek mal sevgisine aşırı bağlılığı da engelleyecektir. ${ }^{214}$

Şu da var ki, dünyalık nimetler konusunda ölçünün, onları elde ederken, haramlara bulaşmamak ve onları verene şükür görevini yerine getirmek, ${ }^{215}$ bu şükrünü daha çok ibadet yaparak göstermek,, ${ }^{216}$ insanların

\footnotetext{
207 Namlı, "Kur'an ve Dünyevileşme ya da Bir Dünya Görüşü Kırılması", 43.

208 Mevdûdî, Tefhîmü'l-Kur'ân, 1: 299.

${ }^{209}$ Kasas 28/77.

210 Namll, "Kur'an ve Dünyevileşme ya da Bir Dünya Görüşü Kırılması", 42.

${ }^{211}$ Kurtubî, el-Câmi'u li ahkâmi'l-Kur'ân, 16: 319.

212 Maturidî, Te'vîlâtü Ehli's-Sünne, 13: 197.

213 Râzî, Mefatîhu'l-gayb, 25: 15.

214 Nesefî, Medârikü't-tenzîl, 2: 657.

215 Mâverdî, en-Nüket ve'l-uyûn, 4: 267.

216 Ebu'l-Haccac Mücahid b. Cebr et-Tabiî el-Mekkî el-Kureyşî el-Mahzumî, Tefsiru Mücahid (Mısır: Daru'l-Fikr el-İslamî el-Hadiseti, 1410/1989), 532.
} 
da sahip olunan mallar üzerinde hakkı olduğunu, ${ }^{217}$ onlara da infak etmek gerektiğini düşünerek harcamak, ${ }^{218}$ konuyla ilgili ayetler, her ne kadar dünya nimetlerinden istifade etmeye izin veriyor olsa da asıl maksadın, dünyayı ahiretin tarlası olarak görüp bu nimetleri ahirete yatırım amacıyla kullanmak ${ }^{219}$ olduğu anlaşılmaktadır.

Elbette ki, dünya ve ahiret arasında tam bir dengeden bahsetmek mümkün olmaz. Çünkü her ikisinin sunduğu imkanlar birbirinden oldukça farklıdır. Ahiret, kalıcı ve salih kullar için sıkıntının olmadığı, nimetlerin ise bol ve kaliteli olduğu bir yer olması açısından bu dünyadan çok öndedir.220 Mekke müşriklerinin aksine ideal olan, dünya ve ahiretten her birine hayatında yer vermek ve her ikisi için de emek ortaya koymaktır. Sadece ahiret tercih edildiği zaman kişi, dünyada sefil bir hayat yaşayacağı gibi Müslümanlar zayıf duruma düşecek ve inkarcllar yeryüzüne hakim olarak Müslümanların inançlarını yaşamalarına müsaade etmeyecektir. Yalnızca dünya tercih edildiğinde ise kişi, herhangi bir sorumluluk taşımadan, helalharam sinırı gözetmeden kazanma ve harcama yoluna gidecek, bunun sonucunda da başkalarına haksızlık yapma, zulmetme konusunda herhangi bir rahatsızlık hissetmeyecektir.

\section{Sonuc}

Mekkî ve Medenî sureler, şekil ve içerik açısından birtakım farklılıklara sahiptir. Bu farklılıklar, dünya hayatıyla ilgili ayetlerde de kendini göstermektedir. Konuyla ilgili ayetler, bazen tamamen farklı bir içerikle yer alırken bazen de her ikisinde aynı konudan bahsedilmektedir.

Mekke döneminde daha çok, insanların maddi imkanları değer ölçüsü olarak kabul edilip onlar hakkında kanaat ortaya konmak suretiyle buna göre bir sonuca ulaşıldığından, Kur'an'da yer alan dünya hayatıyla ilgili ayetlerin, onların, insanlarla ilgili yargılarına işaret ettiği görülmektedir. Diğer taraftan, onlarin dünya ve ahiret algısı, ahirete inançlarının/inançsızlıklarının boyutu, bütün çabalarını sadece bu dünyada daha iyi bir hayat sürmek üzere şekillendirmeleri, adeta taparcasına kendilerini dünyalık nesnelere kaptırmaları, nimeti verenin Allah olduğunu unutmaları da yine Kur'an'da üzerinde durulan hususlardandır.

Medine döneminde inen dünya hayatıyla ilgili ayetlerin ise, Müslümanların, elde ettikleri maddi kazançların, onları asıl gayeleri olan

217 Şevkanî, Fethu'l-kadir, 4: 215.

218 İbn Kesîr, Tefsîru'l-Kur'âni'l-Azîm, 10: 482.

219 Elmalılı, Hak Dini Kur'an Dili, 7: 202.

220 Öztürk, “Kur'an'ın Değer Sisteminde Dünya ve Dünyevi Hayatın Anlamı”, 76-77. 
İslam'ı yeryüzüne hakim kılma, Allah'a iyi bir kul olma hedefinden uzaklaştırmaması gerektiği üzerinde durduğunu görmekteyiz. Diğer taraftan, elde edilen bu kazanımların, Müslümanları günah işlemeye sevk etmemesi, bu imkanları sadece kendi güçleriyle değil, Allah'ın yardımı sayesinde elde ettiklerinin hatırdan çıkarılmaması, bu durumun onları kibirlenmeye ve taşkınlığa sevk etmemesi gerektiği de hatırlatılan diğer hususlardandir.

Mekkî ve Medenî surelerde dünya hayatıyla ile ilgili ortak temanın, onun hakkında genel ifadeler kullanmak ve dünya-ahiret kıyaslaması yapmak şeklinde olduğunu görmekteyiz. Bu surelerde, dünya hayatının cazibesinden, insanlar için imtihan sebebi olabilecek nesnelerden, dünya hayatının geçici olmasından, bütün güzellikleri inanan insanların hak ediyor olmasından bahsedilmektedir. Dünya ahiret denkleminde ise ahiretin öncelenmesi istenmektedir.

Ayetlerden anlıyoruz ki, dünyalık bir şeyi helal yollarla elde etmek ve ondan İslam'ın koyduğu ilkeler çerçevesinde, ihtiyaç sahibi diğer insanları da düşünmek suretiyle istifade etmek yerilen bir davranış tarzı değildir. Yanlış olan, dünyalık herhangi bir nimetin, ahiretin önüne geçirilmesi, kişinin, kulluğuna engel olacak ve kibirlenmesine sebep olacak bir boyuta ulaşmasıdır.xxx.

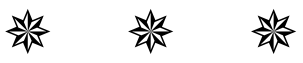

\section{KAYNAKÇA}

ÂLÛSÎ, Şehabeddin Mahmûd. Rûhu'l-me'ânî. 16 cilt. Beyrut: Daru'l-Kütüb elİlmiyye, 1415.

BEYZÂVÎ, Nâsırüddîn. Envârü't-tenzîl ve esrârü't-te'vîl. 5 cilt. Beyrut: Dâru İhyai't-Turasi'l-Arabiyyi, Beyrut, 1418.

BİRIŞIK, Abdülhamit. "Sûre". Türkiye Diyanet Vakfı İslâm Ansiklopedisi. 37: 538-539. İstanbul: TDV Yayınları, 2009.

ELMALILI, M. Hamdi Yazır. Hak Dini Kur'an Dili. İstanbul: Azim Yayınları, ts.

FAYDA, Mustafa "Ensâb", Türkiye Diyanet Vakfı İslâm Ansiklopedisi, c. 11, İstanbul: TDV Yay., 1995, 244-249.

HÂZìN, Ali b. Muhammed. Lübâbü't-te'vîl fî me'âni't-tenzîl. Beyrut: Daru'lKütüb el-İlmiyye, 1415.

İBN AŞÛR, Muhammed Tâhir. et-Tahrîr ve't-tenvîr. 30 cilt. Tunus: Daru Tunusiyye, 1984. 
İBN ATIYYE, el-Endelüsî. el-Muharrerül'-vecîz fi tefsîri'l-Kitâbi'l-'Azîz. 6 cilt. Beyrut: Daru'l-Kütüb el-İlmiyye, 1422.

İBN KESÎR, Ebü'l-Fidâ. Tefsîrü'l-Kur'âni'l-'Azîm. 8 cilt. Byy: Müessesetü Kurtuba, 2000.

İBN MANZÛR, Cemalüddîn. Lisânü'l-Arab. 15 cilt. 3. Baskı. Beyrut: Daru Sadr, 3.baskı, 1414.

İSFEHÂNÎ, Râgıb. el-Müfredât fî garibi'l-Kur'an. 4. Baskı. Beyrut: Dâru'lMarife, 2005/1426.

BURSEVÎ, İsmail Hakkı. Rûhu'l-beyân fî tefsîri'l-Kur'ân. 10 cilt. Beyrut: Daru İhyai't-Turasi'l-Arabiyyi, Beyrut, ts.

İZUTSU, Toshihiko. Kur'an'da Allah ve İnsan, (Çev. Süleyman Ateş). Ankara: Ankara Üniversitesi Basımevi, 1975.

KARAMAN, Hayreddin, Mustafa Çağrıcı, İbrahim Kafi Dönmez ve Sadrettin Gümüş. Kur'an Yolu Türkçe Meal ve Tefsir. Ankara: Diyanet İşleri Başkanlığı Yayınları, 2014.

KÂSIMÎ, Cemâleddîn. Mehâsinü't-te'vîl. 9 cilt. Beyrut: Daru'l-Kütüb el-İlmiyye, ts. 1418.

KURTUBÎ, Muhammed b. Ahmed. el-Câmi' li-ahkâmi'l-Kur'ân. 20 cilt. Beyrut: Müessesetü Risale, 2006.

MÂTURÎDÎ, Ebû Mansûr Muhammed. Te'vîlâtü Ehli's-Sünne. 10 cilt. Beyrut: Daru'l-Kütüb el-İlmiyye, 1426/2005.

MÂVERDÎ, Ebü'l-Hasen. en-Nüket ve'l-'uyûn. 6 cilt. Beyrut: Daru'l-Kütüb el İlmiyye, ts.

MERÂGÎ, Ahmed Mustafa. Tefsîrü'l-Merâgî. 30 cilt. Mısır: Mustafa Elbânî elHalebî ve Evlâduhu, 1365/1946.

MEVDÛDÎ, Ebü'l-A'la. Tefhîmü'l-Kur'ân. trc. Muhammed Han Kayanî ve dğr. 2. Baskı. 7 cilt. İstanbul: İnsan Yayınları, 1995.

MÜCÂHİD b. Cebr, Ebü'l-Haccâc. Tefsîru Mücâhid. Mısır: Daru'l-Fikr el-İslamî el-Hadiseti, 1410/1989.

NAMLI, Tuncer. "Kur'an ve Dünyevileşme ya da Bir Dünya Görüşü Kırılması". Eski Yeni: Üç Aylık Düşünce Dergisi 13 (2009): 40-53.

NESEFî, Ebu'l-Berekat Abdullah b. Ahmed b. Mahmud Hafızuddin. Medariku't-tenzil ve hakaiku't-tevil. Beyrut: Daru'l-Kelime't-Tayyib, $1419 / 1998$. 
ÖZTÜRK, Mustafa. “Kur'an'ın Değer Sisteminde Dünya ve Dünyevi Hayatın Anlamı". Tasavvuf: İlmî ve Akademik Araştırma Dergisi 7: 16 (2006): 65-86.

ÖZTÜRK, Yaşar Nuri. Kuran'ın Temel Kavramları. İstanbul: Yeni Boyut, 19.baski, 1999.

RÂZÎ, Fahrüddîn. Mefâtîhu'l-gayb. et-Tefsîrü'l-kebîr. 32 cilt. Daru İhyai'tTurasi'l-Arabiyyi, Beyrut, 1420.

SA'LỉBÎ, Ahmed b. Muhammed b. İbrahim es-Salibî. el-Keş̧f ve'l-beyân. 3. Baskı. 10 cilt. Beyrut: Daru İhyai't-Turasi'l-Arabiyyi, 1422/2002.

SEÂLỉBî, Ebu Zeyd Abdurrahman b. Muhammed b. Mahluf. el-Cevâhirü'lhisân fî tefsîri'l-Kur'ân. 5 cilt. Beyrut: Daru İhyai't-Turasi'l-Arabiyyi, 1418.

SÜYÛTî, Ebü'l-Fazl Celâlüddîn Abdurrahmân b. Ebî Bekr b. Muhammed elHudayrî eș-Şâfiî. el-îtkân fî ulûmi'l-Kur'ân. Tahkîk/Tahrîc: Şuayb Arnavut. Beyrut: Müessesetü'r-risale, 1429/2008.

ŞEVKÂNÎ, Ebû Abdillâh. Fethu'l-kadîr el-câmi' fenneyi'r-rivâye ve'd-dirâye min 'ilmi't-tefsîr. 6 cilt. Dımeşk: Daru İbn Kesir, 1414.

ŞíRBİNî, Şemsüddin Muhammed b. Ahmed el-Hatib eș-Șafî. es-Siracü'l-münir fi'l-İaneti ala mağrifeti ba'di meani kelami Rabbina el-Hakim el-Habir. Kahire: Matbaatu Bulak, 1285.

TABERÎ, Muhammed b. Cerîr. Câmi'u'l-beyân 'an te'vîli âyi'l-Kur'ân. 4 cilt. Kahire: Daru Hicr, 2001.

TANTÂVÎ, Muhammed Seyyid. et-Tefsîrüll-vasît li'l-Kur'âni'l-kerîm. 15 cilt. Kahire: Daru Nehda, 1998.

ZEMAHŞERÎ, Ebü'l-Kâsım. el-Keşşaff 'an hakâ'ikı gavâmizi't-tenzîl ve 'uyûni'lekâvîl fî vücûhi't-te'vîl. 3. Baskı. 4 cilt. Beyrut: Daru'l-Kitab el Arabiyyi, 1407.

ZÜRKÂNÎ, Muhammed Abdülazîm. Menâhilu'l-irfân fî ulûmi'l-Kur'an. Beyrut: Dâru-Kuteybe, 1422/2001.

ZERKEŞî, Ebû Abdillâh Bedrüddîn Muhammed b. Bahâdır b. Abdillâh et-Türkî el-Mısrî el-Minhâcî eș-Şâfiî. el-Burhân fî 'ulûmi'l-Ḳur'ân. Tahkîk: Muhammed Ebu'l-Fazl İbrahim. Kahire: Mektebetü Dârü't-Türâs, ts.

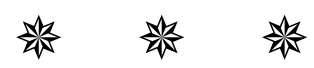




\title{
THE PERCEPTION OF THE WORLD IN THE CONTEXT OF MECCIAN AND MEDENIAN SURAH
}

\author{
(D) Ahmet ÖZDEMIR ${ }^{\mathrm{a}}$
}

\section{Extended Abstract}

The Qur'an says that the life of the world is to boast. From this point, people have superiority over others as they have. They always see themselves in a higher position. They spend time with worldly things like a child playing a game. However, they are unaware that every game is a last. Those who are aware of it better evaluate their time. Not the means prefer to aim.

God must be at the center of people's lives. The emphasis of the Qur'an is in this direction. Other elements remain in the second position. Servant must keep his author in his heart at any moment, despite the factors that keep him occupied in the world. The path he draws must be a guide to himself. Worldly objects of worship should not be an obstacle. He must spend every moment with the consciousness of worship. He, should strive to earn profit halal. He must put a distance between sins. He should know the value of his time. He must be in the consciousness that he will account for everything he does in the world in the hereafter. He should take away from his life what causes him to get away from Allah.

World life is not completely negative structure. The Hereafter will be negative when neglected. Because the neglect of this world will result in Muslims losing their sovereignty and the disbelievers dominating them. In the Qur'an, being rich is never condemned. Fortune must not take man captive. He must not make him forget God The point to be noted at this point is the protection of the balance between the two. In other words, it is the preference of a world that will give priority to the world without forgetting its share. For the hereafter, as if he would die tomorrow, to work for the

\footnotetext{
a Asst. Prof., Tokat Gaziosmanpasa University Theology Faculty, 
world as if he would never die. I mean, it is not appropriate for a Muslim to lazy. He must spend every moment with a struggle. He has no time to waste. Every day should work more than the previous day. He should produce new things. He must put forth something for himself and for all Muslims. He should be not passive, but thinking and producing.

There are differences in the surahs of Mecca and Medina. The reason for this is the change and development of religious perceptions. The verses in Mecca are mostly related to the belief dimension of religion. Because there are belief problems in Mecca. The Meccans are the only people who work for the world. They did not believe in the hereafter. They were evaluating people according to their wealth. However, it is stated that he will be given only the one who wants the world. They were reminded that it was Allah who first gave them all.

In Medina, the area of application has been given importance. The structure and characteristics of the blessings used in the life of the world during the period of Macca, the views of the unbeliever on these blessings are discussed. He was asked to serve God. During the Medina period, Muslims were enriched. That is why their perception of the world has also changed. Allah has warned them not to have looseness in their understanding of worship. He wanted the Hereafter to value the world more. Emphasized that the world's goods are worthless. It is reminded that Allah is the Giver of Blessings. Allah wanted them to work hard for Islam. He wanted world life not to distract them from these targets. He reminded me of the achievements they had with God's help. He banned them from seeing others as small.

There are also common issues described in both periods. The fact that the world was beautified is one of the topics described in both periods. Both of them were not neglected. Recalled that the world is the test area. World life is said to be temporary. Muslims of all the beauty of the world deservedly described. İt is emphasized that the life of the world is temporary. The world's blessings were not wanted to be coveted. He was asked to give more value to the Hereafter.

In this study, it will be tried to reveal the issues highlighted in Qur'an view of world life in the verses following the period of Mecca and Medinah.

Keywords: Tafsir, Qur'an, Meccian-Medenian Surah, World, Human, Exam.

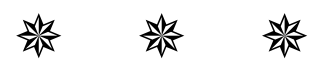

